\title{
The effect of in vitro corrosion on the mechanical properties of metallic high strength biodegradable surgical threads
}

\author{
Andrij Milenin ${ }^{1} \oplus$ - Piotr Kustra ${ }^{1} \cdot$ Dorota Byrska-Wójcik ${ }^{1}$ Mirosław Wróbel ${ }^{1} \cdot$ Marek Paćko $^{1}$. \\ Joanna Sulej-Chojnacka² · Sława Matuszyńska² $\cdot$ Bartłomiej Płonka ${ }^{3}$
}

Received: 11 December 2019 / Revised: 15 February 2020 / Accepted: 8 May 2020 / Published online: 20 May 2020

(c) The Author(s) 2020

\begin{abstract}
High strength biodegradable surgical threads are in demand for surgical practice. Nowadays, such threads can be made of metallic materials such as magnesium, zinc or alloys based on these metals. In current paper, manufacturing technology of biodegradable surgical threads of $\mathrm{Mg}-\mathrm{Ca}$ alloys and of pure $\mathrm{Zn}$ was developed and basic properties of the obtained product have been characterized. The influence of in vitro corrosion in bovine serum simulating environment in the mammal's body on the surgical threads mechanical properties was determined. It was found that $\mathrm{Zn}$ and hot extruded alloys $\mathrm{MgCa} 0.9$ and $\mathrm{MgCa} 1.2$ can be recommended as a candidate for the future study in vivo. Properties of the room temperature drawn wires of the alloy $\mathrm{MgCa} 0.7$ are not sufficient for its application as surgical threads.
\end{abstract}

Keywords Biodegradable surgical threads $\cdot$ Zinc $\cdot$ Magnesium-calcium alloy $\cdot$ Mechanical properties $\cdot$ In vitro corrosion

\section{Introduction}

Sterilized threads or strings use in surgery both inside and outside the body is defined by the words surgical suture and ligature. The suture is the threads with a surgical needle attached [1]. Suture is used to stitch together the edges of various tissues, e.g., skin, fascia, muscle, tendon, peritoneum, etc. The surgical thread (ST) tied around a blood vessel or to constrict the tissues can be called as the ligature. The ligature is used to prevent bleeding, or to treat abnormalities in other parts of the body [2]. There is evidence that sutures and ligatures were used by both Egyptians and Syrians as far back as 3000 B.C.E. [3]. The paper [4] describes the history of the surgery in other countries from 500 B.C.E. A historical account of sutures and ligatures can be found elsewhere. The first usage of catgut or hair as suture is dated

Andrij Milenin

milenin@agh.edu.pl

1 AGH University of Science and Technology, al. Mickiewicza 30, 30-059 Krakow, Poland

2 Lukasiewicz Research Network - Metal Forming Institute, 14 Jana Pawla II St., 61-139 Poznan, Poland

3 Light Metals Division, Lukasiewicz Research Network - Institute of Non-Ferrous Metals, ul. Pilsudskiego 19, 32-050 Skawina, Poland in 1600 B.C.E. by Greek surgeon Galen of Pergamon [5]. Surgical needles were made from bones or a metals wire [6]. In the past, gold, silver, copper and aluminum bronze was used for the purpose [7]. Very short characterization of the ideal material for sutures can be found in [8]. Some of papers are also focused on more limited application of the sutures and ligatures, for example work [9] is devoted to the sutures used only in pelvic surgery. The surgical needles are made of high quality stainless steel grades AISI 302, AISI 455 and AISI 420 [10]. The shape and size of needle is dependent on the area of their application [11].

ST that maintain their tensile strength for longer than 60 days are considered as nonabsorbable by the patient body so, should be removed after recovery. The ones that undergo rapid degradation in tissues, losing their tensile strength within 60 days, are considered as the absorbable ones. Absorbable ST are designed for temporarily use, until tissues connected by them have healed sufficiently to withstand normal stress. ST can be made from biological materials such as horse hair [12], human hair [13], catgut [14], collagen [15] or silk [16], from some synthetic materials as the thermoplastic polymers or from metals. Different metal wires were tried to use as STs (i.e., gold, silver, platinum, brass, lead, titanium, aluminum, magnesium and zinc). Historical account of metallic ST was published by Babcock [17]. However, after introduction of synthetic materials 
during the second part of twentieth century, the absorbable and nonabsorbable thermoplastic polymers are predominantly applied as threads in the surgery practice [18]. They are synthesized mainly from lactide or glycolide [19] and are known as the polylactic acid (PLA) or the polyglycolic acid (PGA) ones, respectively. Despite the fact that polymer STs are regarded as biocompatible, adverse effects on surrounding tissues can be observed due to their implantation [20]. The overview of the biodegradable surgical materials used nowadays can be found in the paper [21]. Research about biocorrosion and biocompatibility of PLGA is published in [22]. The main problem is the local $\mathrm{pH}$ shifts and debris diffusion [23]. So, the swelling of the soft tissue can last up to 6 years after implantation [23]. Moreover, relatively low mechanical properties are an important disadvantage of the polymers STs. The Young modulus of the PLA and PGA is in the range of 1.5-3.6 GPa and of 5-7 GPa, respectively [24]. The tensile strength is also relatively low (i.e., about 40-50 MPa for PGA and 15-75 MPa for PLA [25]). The ability in the thread cross-sectional area increase is limited because a thicker monofilament ST has wire-like properties and thus the thread ends can cause local injuries. For this reason, monofilament STs can only be used in smaller sizes [26]. On the other hand, multifilament STs are more exposed to bacterial contamination and have a capillary effect which is also undesirable. For these reasons, polymers cannot be recommended for highly loaded STs. The other problem with polymer STs is related to low creep resistance [27] what significantly limit sterilization temperature and make the sterilization process difficult. The promising alternative for polymer STs can be the ones made of metals. At present the only metallic ST used, is the nonabsorbable one made of 316L stainless steel [28]. An application 316L TS for abdominal wall closure, sternum closure, retention, skin closure, a variety of orthopedic procedures, and neurosurgery is practiced. Biodegradation of $\mathrm{Fe}, \mathrm{Mg}$ or $\mathrm{Zn}$ and theirs alloys in mammals body is well known, so ST made of these materials can be a good alternative to those made of polymers and the stainless steel [29]. In the literature, there are numerous works devoted to corrosion of magnesium alloys [30]. Research on $\mathrm{Mg}-\mathrm{Zn}$ alloys, pure $\mathrm{Mg}$ and $\mathrm{Mg}-\mathrm{Zn}-\mathrm{Ca}$ alloys can be found in [31, 32] and [33], respectively. Chiu et al. studied the fluoride conversion coating on $\mathrm{Mg}$ implants [34]. Results of in vitro corrosion of ZEK100 alloy are published in [35]. The overview of Zinc's possibility of usage as material for biodegradable implants can be found in [36]. These metals have relatively high strength, in contrast to the ST polymers. The Young's modulus of magnesium is $45 \mathrm{GPa}$, so it is about 10 times higher than for PGA. The Young's modulus of $\mathrm{Zn}$ is even higher and for $\mathrm{Fe}$ it is very high. For pure zinc it is equal to $94 \mathrm{GPa}$ and to $100-110 \mathrm{GPa}$ for the Zn-based alloys. The Young's modulus of Fe-alloys covers the range of 150-210 GPa. The biodegradable characteristics of pure iron were studied in paper [37]. However, as concluded in [21], the use of iron as material for ST is not even suggested in the literature. The mechanical properties of sutures made from magnesium were tested by Seitz et al. [38] and Witte et al. [39]. Seitz et al. characterized also other magnesium alloys, for example $\mathrm{MgNd} 2$ [40]. In contrast to the polymers ST the yield strength of the biodegradable metals also is high (70-220 MPa, 150-296 MPa and 170-110 MPa for Mg-alloys [41], Fe-based alloys [42] and Zn-based alloys [43], respectively, so there is no risk of the ST break or uncontrolled plastic deformation, and its plasticity is sufficient to make a surgical knot as it was shown elsewhere. The tensile strength of a $\mathrm{Zn}$ thread knot is only $10 \%$ lower than its tensile strength [44] while for polymer STs the 50\% decrease in the tensile strength is observed [45]. Moreover, to other advantages of a metallic ST belong: no dimension change due to a fluid action and a very low one due to change in the temperature of the body undergoing surgery as well as the good visibility by naked eye or by ultrasonic and the X-ray devices. The sterilization of metal ST is also much easier because the creep resistance of $\mathrm{Zn}$ and $\mathrm{Mg}$ is sufficient and that of $\mathrm{Fe}$ is even more than enough. The biocompatibility of considered metallic elements is adequate because all of them (i.e., $\mathrm{Fe}, \mathrm{Mg}$ and $\mathrm{Zn}$ ) are the natural element of the body and they participate in many processes in organism. The biodegradation of metallic ST made of Fe and $\mathrm{Zn}$ do not result in gas release. Unfortunately, the iron degradation rate in the mammalian body is too slow. That is why the use of iron-based ST is limited. The zinc degradation rate can be satisfactory [36], though, in some orthopedic therapy is reported to be too slow considering the recovery process of injured tissue [46]. Its safe biodegradation and excellent biocompability was recently reported by Drelich et al. [47] during 20 months of testing a wire implanted into abdominal aorta of Sprague-Dawely rat. However, change in the mechanical properties of the zinc wire during biodegradation is not enough recognized.

According to Witte [48], for the first time, use of magnesium wires were successfully tested by E.C. Huse in 1878 as ligatures to stop bleeding vessels in a radial artery and in the operation for varicocele. Also, the wires were used in 1892 by E. Payr as biodegradable implants. Some years later magnesium was tested in vivo on rabbits and dogs by Lambotte [49]. Broader clinical studies started around the end of first half of twentieth century [50] after implementation of large scale magnesium production technologies. In the process of the $\mathrm{Mg}$ biodegradation, the hydrogen gas is released, which can form gas cavities and cause problems with tissue healing. This issue temporarily suspended any attempts to use magnesium as biomaterial [49]. However, if the rate of the magnesium ST degradation will be decreased, (e.g., by alloying) the hydrogen can be metabolized. There is an evidence suggesting that the degradation 
rate of Mg-based ST can be safely control by alloying using bio-accepted elements (e.g., Ca) [51]. However, Wan et al. [52] suggested that calcium content can also significantly affect the ST mechanical properties since the increase in the Ca content from 0.6 to $2.0 \%$ led to the decrease plastic properties and strength of the material as well as the corrosion resistance. From this point of view, an alloy with the content of $0.6 \% \mathrm{Ca}$ is recognized as the best one. However, to the best of our knowledge, corrosion of this alloy was evaluated only by electrochemical studies but no in vitro test has been performed. In addition, only cast material was examined, despite the fact that deformed metals are often used for some biomedical applications (e.g., surgical screws). Due to the difference in microstructure and in chemical homogeneity, the data obtained from a cast material cannot be directly extend to a deformed one such as a wire that are subjected to a greater degree of plastic deformation. For these reasons, we do not have enough knowledge sufficient for practical application of $\mathrm{Mg}-\mathrm{Ca}$ alloys, e.g., about the change in the wire mechanical properties during the biodegradation in the mammals body.

The production of the magnesium alloys wire is relatively difficult. The main limiting factor here is low ductility of these alloys. For this reason, according to our experience, to obtain a wire suitable for surgical knots, the multi-stage drawing at room temperature with annealing between drawing passes or hot drawing process should be applied (Refs. [53] and [54], respectively).

The aim of the paper is to suggest different technologies for the manufacturing of $\mathrm{Mg}-\mathrm{Ca}$ alloys and pure $\mathrm{Zn}$ base ST and to study the corrosion effect on their mechanical properties. The corrosion test was performed in a solution simulating the chemical environment of the mammalian body. A comparative estimation of these materials applicability as potential candidates for the biodegradable ST was the practical purpose of the study.

\section{Wire materials and manufacturing process}

Four metals were selected for the wires investigated in the present paper (i.e., technically pure $\mathrm{Zn}$ and alloys $\mathrm{MgCa} 0.7$, $\mathrm{MgCa} 0.9$ and $\mathrm{MgCa} 1.2)$. The diameter of the wire was chosen as equal to $1-1.8 \mathrm{~mm}$ because such a diameter are suitable for highly load ST dedicated for the veterinary medicine.

\subsection{Zinc}

Wires of commercial purity zinc were used in this study. The metal quality corresponds to the standard DIN EN ISO 14919 as well as to the Z1 "white" grade of $\mathrm{Zn}$ according to the EN 1179 standard. Wires with two different diameters were used. The first one with diameter of $1.6 \mathrm{~mm}$ was industrially produced on the continuous Properzi line (i.e., by the continuous casting followed by the room temperature rolling and drawing). The second wire with the final diameter of $1 \mathrm{~mm}$ was laboratory manufactured from the first one by the room temperature drawing. Drawing of this wire was carried out in 11 passes. The drawing speed and elongation per pass was equal to $50 \mathrm{~mm} / \mathrm{s}$ and to $10 \%$, respectively. A solution of soap in water was used as a lubricant.

\section{$2.2 \mathrm{Mg}-\mathrm{Ca}$ alloys}

The $\mathrm{Mg}-\mathrm{Ca}$ alloy wires belong to the other group of the tested materials. The alloys with chemical composition (measured by a spark gap spectrometer) shown in Table 1 were prepared from magnesium of commercial purity and the binary master alloy $\mathrm{MgCa} 30$ (30 wt $\% \mathrm{Ca}+70 \mathrm{wt} \% \mathrm{Mg}$ ). The metals were melted in a Hindenlang resistance furnace with capacity of $150 \mathrm{~kg}$ and cast in the HOT-TOP crystallizer with diameter of $102 \mathrm{~mm}$. Both processes were conducted under protective atmosphere of $\mathrm{N}+\mathrm{SF}_{6}$. The casting from temperature of $690-710{ }^{\circ} \mathrm{C}$ was done with the rate of $2-3 \mathrm{~mm} / \mathrm{s}$. The chill zone of the ingots was removed by machining, and the obtained billet was a multi channel die extruded on the wires with diameter of $1.8 \mathrm{~mm}$ (Fig. 1). The deformation zone temperature $460{ }^{\circ} \mathrm{C}$ and the extrusion velocity of $0.5 \mathrm{~mm} / \mathrm{s}$ were selected by experimental correction of the parameters anticipated by the finite element method (FEM) simulation by using the commercial software QFORM v.8.2. FEM modeling showed that the effective strain of the material during extrusion reached tremendous values of 6.0-7.0 (i.e., 600-700\%). Then, the extruded rods were multi pass cold drawn at room temperature to the wire with final diameter of $1 \mathrm{~mm}$. The drawing speed and elongation per pass was equal to $10 \mathrm{~mm} / \mathrm{s}$ and to $10 \%$, respectively.
Table 1 The chemical composition of the $\mathrm{Mg}-\mathrm{Ca}$ alloys

\begin{tabular}{llllllllll}
\hline Alloy & \multicolumn{2}{l}{ Composition in $\mathrm{wt} \%$} \\
\cline { 2 - 10 } & $\mathrm{Ca}$ & $\mathrm{Mg}$ & $\mathrm{Zn}$ & $\mathrm{Mn}$ & $\mathrm{Pb}$ & $\mathrm{Al}$ & $\mathrm{Fe}$ & $\mathrm{Si}$ & $\begin{array}{r}\text { Acceptable } \\
\text { admixtures }\end{array}$ \\
\hline $\mathrm{MgCa} 0.7$ & 0.70 & 99.6416 & 0.0015 & 0.01753 & 0.00112 & 0.02646 & 0.00269 & 0.01699 & 0.29 \\
$\mathrm{MgCa} 0.9$ & 0.94 & 99.6304 & 0.0022 & 0.01737 & 0.00120 & 0.00958 & 0.00309 & 0.01709 & 0.32 \\
$\mathrm{MgCa} 1.2$ & 1.14 & 99.5882 & 0.0021 & 0.01725 & 0.00126 & 0.01300 & 0.00315 & 0.01857 & 0.35 \\
\hline
\end{tabular}



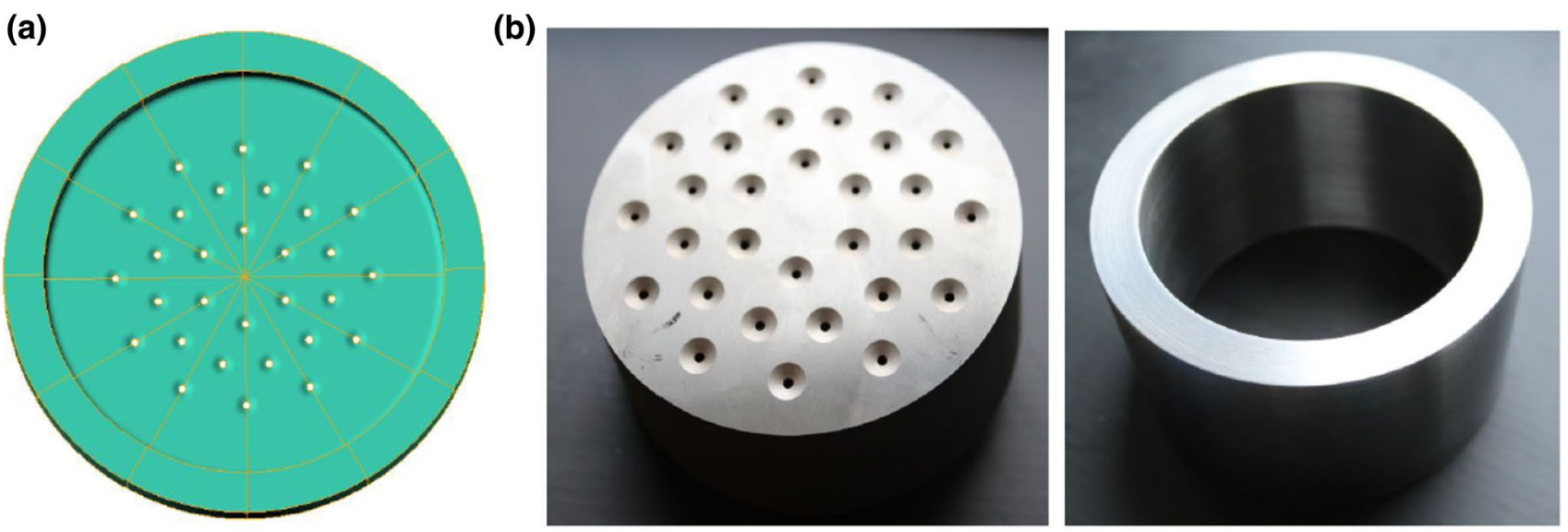

(c)

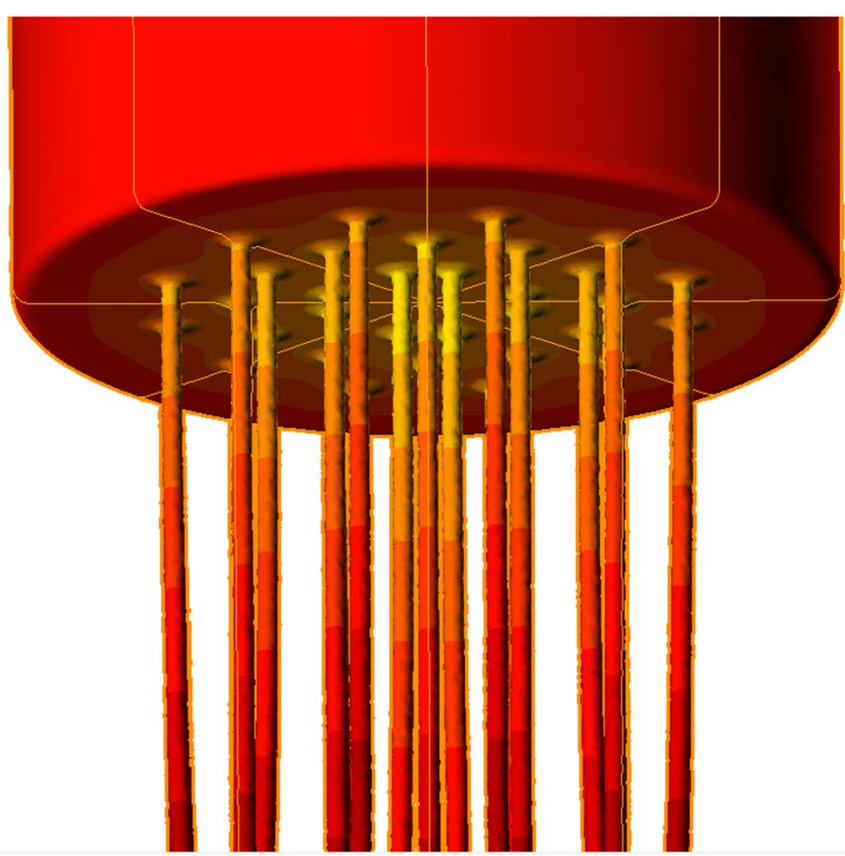

(d)

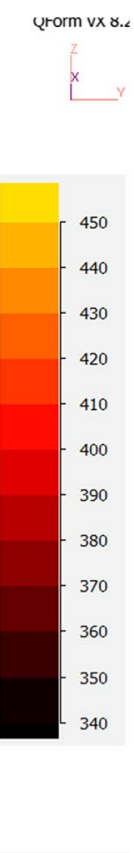

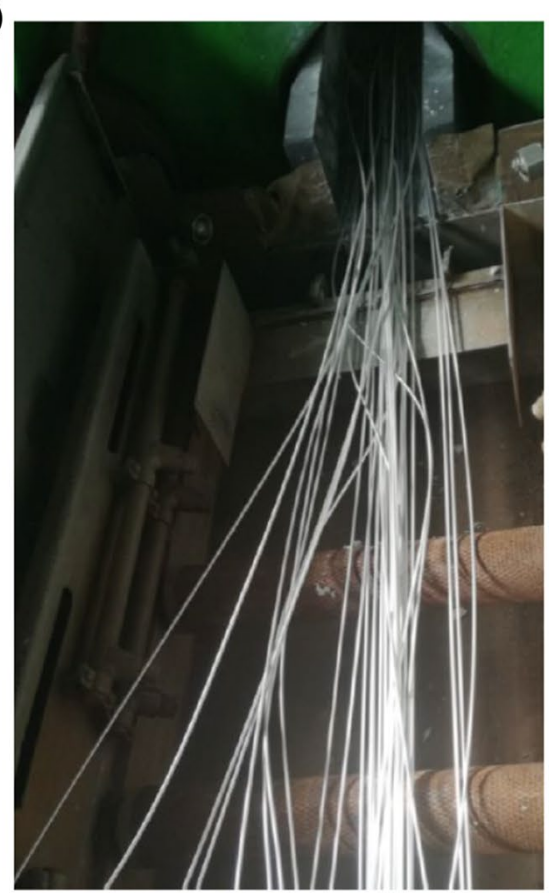

Fig. 1 Extrusion of Mg-Ca alloys: a FEM model of matrix for extrusion; $\mathbf{b}$ view of produced matrix; $\mathbf{c}$ FEM simulation of temperature distribution in material during extrusion process; $\mathbf{d}$ extruded wires

A short (15-20 s) annealing at $320^{\circ} \mathrm{C}$ was applied between consecutive drawing passes. A mixture of graphite and oil was used as a lubricant.

\section{Experimental procedures}

The in vitro corrosion tests were performed in a mixture of bovine serum supplied by Biowest (catalog No. S0250) [55]. A protein content in the mixture was equal to $30 \mathrm{~g} / \mathrm{l}$. Sodium azide $(0.3 \mathrm{wt} \%)$ and $20 \mathrm{mM}$ of the ethylenediaminetetraacetic acid were added to the solution for the purpose of inhibiting bacteria growth and binding calcium ions. The mixture was filtered through a sterile filter (pore size $20 \mu \mathrm{m}$ ).
During corrosion tests, the $\mathrm{pH}$ value and the temperature of the corrosion medium was kept as equal to 7.2-7.4 and $37 \pm 0.1{ }^{\circ} \mathrm{C}$, respectively. The protein concentration was monitored by a Genesys ${ }^{\mathrm{TM}} 20$ spectrophotometer (Spectronic Instruments, USA). During the in vitro corrosion test all recommendations given by the ASTM F732-00 standard were satisfied.

Two types of studies have been performed. In the first case, the influence of the corrosion time on the mechanical properties was investigated. The duration of corrosion was 3, 7, 14, 21, 28, and 35 days. These studies were performed for the following materials: $\mathrm{Zn}, d=1.6 \mathrm{~mm}$; $\mathrm{MgCa} 0.9, d=1.8 \mathrm{~mm}$; MgCa1.2, $d=1.8 \mathrm{~mm}$. In the second type of studies, the change in the mass of the sample 
during corrosion was investigated. Weighing of samples was carried out after 3, 7, 14, 21, 28 days for materials $\mathrm{Zn}$, $d=1.6 \mathrm{~mm}, \mathrm{Zn}, d=1 \mathrm{~mm} ; \mathrm{MgCa} 07, d=1 \mathrm{~mm} ; \mathrm{MgCa} 0.9$, $d=1.8 \mathrm{~mm}$; MgCa1.2, $d=1.8 \mathrm{~mm}$ and after 3, 7, 14 days for $\mathrm{MgCa} 0.7, d=1.8 \mathrm{~mm}$. After each test period, the samples were removed from the corrosion medium and a change in their weight was determined using a laboratory balance with accuracy of $0.00001 \mathrm{~g}$. Immediately before the test and before each weighting, samples were thoroughly cleaned in the distillated water then ultrasonically in ethanol and finally dried out at room temperature.

The mechanical properties of the initial and corroded materials were determined by the tensile test on a Zwick250 tensile machine equipped with specially designed grips for wires [45], a modified version of the setup shown in the [56]. The length of the tested samples was $250 \mathrm{~mm}$. The tests were done at room temperature and the deformation velocity $20 \mathrm{~mm} / \mathrm{min}$.

The Empyrean Panalytical X-ray laboratory diffractometer was used during X-ray diffraction (XRD) measurements. The incident beam of $\mathrm{CuK} \alpha$ radiation was formed by the parallel Goebe mirror (divergence $0.02^{\circ}$ ) and the soller slit $(0.04 \mathrm{rad})$. Similar soller slit and the parallelplate collimator (divergence $0.18^{\circ}$ ) supplemented with a nickel filter were placed at the diffracted beam in the front of the PIXCel 3D detector. The Williamson-Hall method [57] was used for the residual strain and the crystalline size calculations from XRD patterns. The patterns were measured in symmetrical geometry for the $2 \theta$ angle range. Calculations were performed using the software HighScore Plus v.3.05 by Panalytical B.V.

The Zeiss Axio Imager M1m light microscope and the Hitachi S-3500N scanning electron microscope (SEM) were used for studies of microstructure and corrosion effects, respectively.

\section{Results and discussion}

\subsection{Materials before the corrosion test}

Since the intensity of corrosion depends not only on the chemical composition of the material, but also on its microstructure and phase composition, a detailed analysis of the initial materials was performed. The XRD measurements have shown that, zinc is a single phase material with the hexagonal close-packed (hcp) structure, as it was expected. On the other hand, $\mathrm{Mg}-\mathrm{Ca}$ alloys are two phase materials (Fig. 2). The dominant phase in these alloys has the hcp structure, space group P63/mmc (space group number 194) and the lattice parameters nearly the same as pure magnesium (i.e., $a=3.2085 \mathrm{~A}, c=5.21 .06 \mathrm{~A}$, the reference code no. 01-071-3765). This indicates that this phase is a solid solution of calcium in magnesium and the calcium content in it is very small, if any, which is consistent with the equilibrium phase diagram $\mathrm{Mg}-\mathrm{Ca}$ published by MezbahulIslam et al. [58], Aljarrah et al. [59], Zhong et al. [60] and Baker [61]. The second phase has the $\mathrm{CaMg}_{2}$ chemistry. This phase has the same crystal structure and the same symmetry group as the matrix but its lattice parameters are significantly larger (i.e., $a=-6.23 \mathrm{~A}, c=10.12 \mathrm{~A}$ ). These data fit well to the X-ray reference no. 03-065-3583. Together with the difference in the structure factor values this allows for the unambiguous identification of this phase as $\mathrm{CaMg}_{2}$. The relative intensities of the $\mathrm{CaMg}_{2}$ phase peaks increase with the increase in $\mathrm{Ca}$ the content in the alloy. This, in turn, indicates for the larger volume fraction of this phase (see inset in Fig. 2).

The average density of particles in materials used in the study was significantly higher than the value shown by Liu et al. [62] for the alloy MgCa1.5 (see Fig. 1 in [62]). The size of $\mathrm{CaMg}_{2}$ phase particles was about $3 \mu \mathrm{m}$. The particles form well-defined bands elongated in the direction of the material flow (Fig. 3). (a) is $\mathrm{CaMg}_{2}$

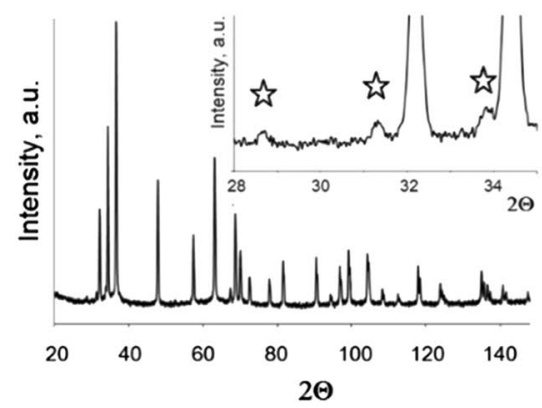

(b)

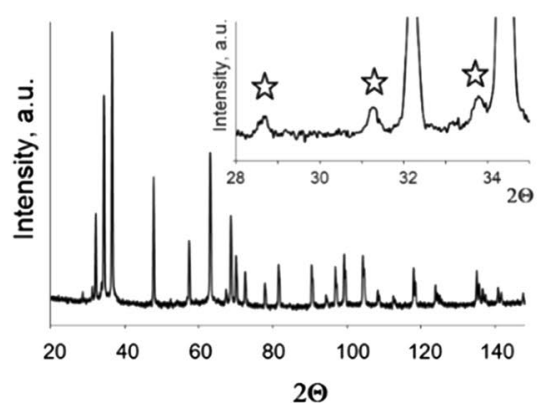

(c)

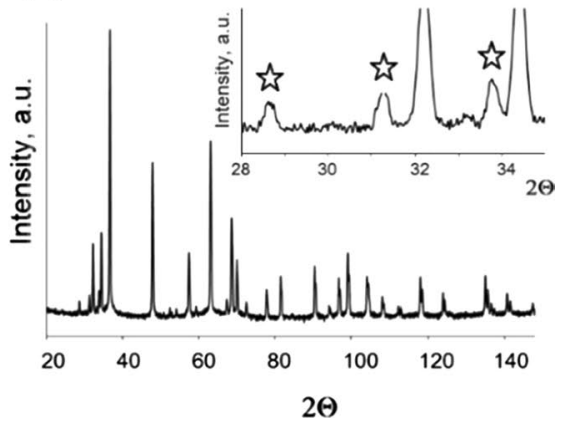

Fig. 2 XRD patterns for $\mathrm{MgCa}$ alloys after extrusion: a $0.7 \% \mathrm{Ca}, \mathbf{b} 0.9 \% \mathrm{Ca}, \mathbf{c} 1.2 \% \mathrm{Ca}$, the intensity axis arbitrary unit (a.u.) in figures a, b and $\mathrm{c}$ is the same 
(a)

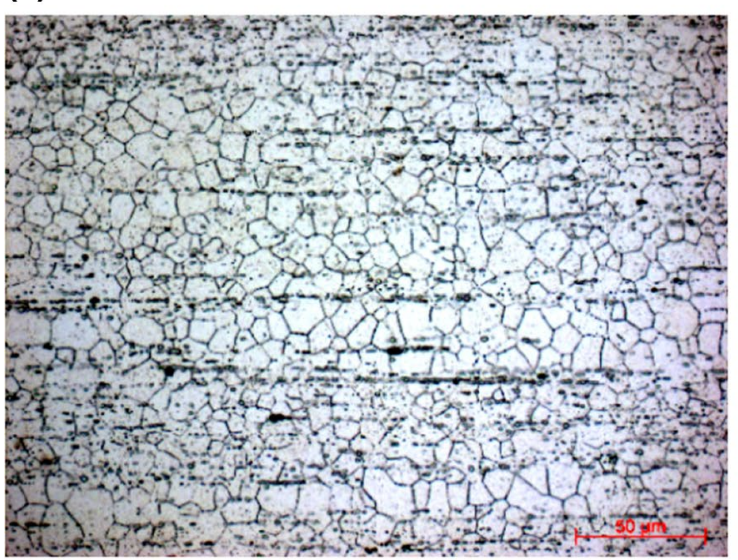

(c)



(b)

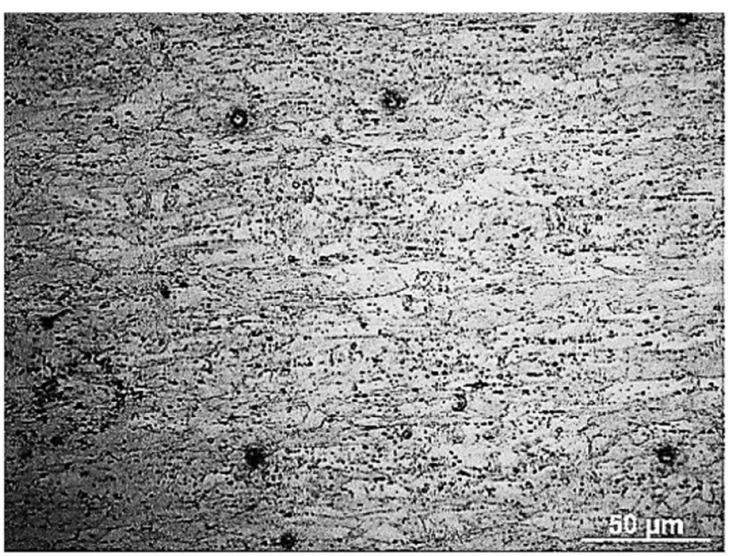

(d)

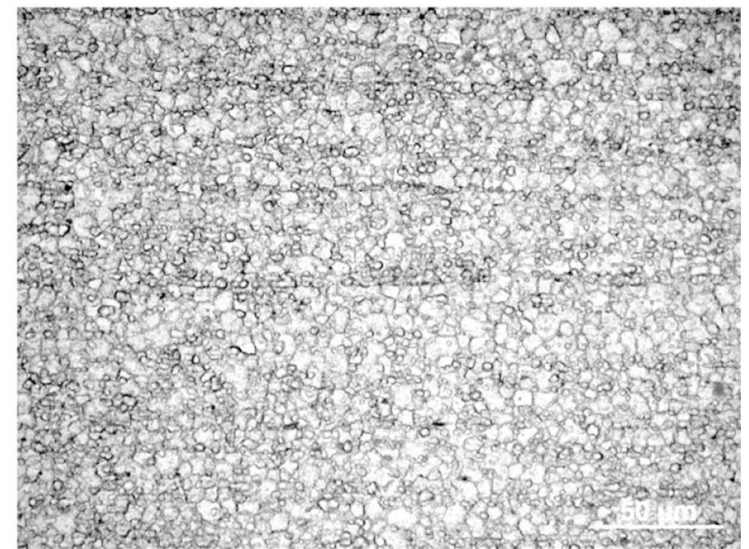

Fig. 3 Typical microstructure in longitudinal section of the $\mathrm{Mg}-\mathrm{Ca}$ alloys wires with: $0.7 \% \mathrm{Ca}$ after extrusion (a) and after cold drawing (b); $0.9 \% \mathrm{Ca}(\mathbf{c})$ and $1.2 \% \mathrm{Ca}(\mathbf{d})$ after extrusion. The horizontal axis is the direction of drawing and extrusion. Light microscopy

The particle density observed in our experiment within the band region is greater than between the bands. This is clearly seen for alloys containing 0.7 and $0.9 \% \mathrm{Ca}$. In regions with the higher density of particles, the average grain size of matrix was equal to a few micrometers. On the other hand, in the area with the lower particles density it was about $20 \mu \mathrm{m}$ for the alloys with $0.7 \% \mathrm{Ca}$ and about $10 \mu \mathrm{m}$ for alloys with 0.9 and $1.2 \% \mathrm{Ca}$. The grain size of the materials annealed after deformation was similar indicating complete recrystallization. This is evidenced by almost complete lack of the matrix lattice deformations determined from the Williamson-Hall plots (Fig. 4). Very small values (below $0.08 \%$ ) can result from the sample preparation procedure. It has been shown, that such a low lattice deformation is typical for the recrystallized $\mathrm{Ag}, \mathrm{Au}, \mathrm{Fe}[63]$ and $\mathrm{Nb}$ and $\mathrm{Zr}$ [64]. Figure 4 also shows that the matrix crystallite size
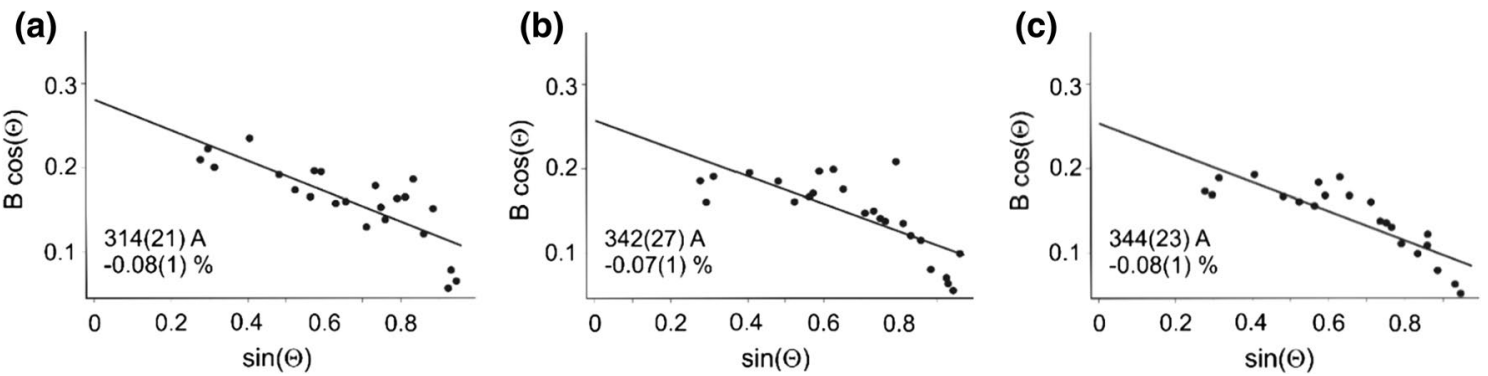

Fig. 4 The Williamson-Hall plot for the Mg matrix, the Mg-Ca alloys: a $0.7 \% \mathrm{Ca}$, b $0.9 \% \mathrm{Ca}, \mathbf{c} 1.2 \% \mathrm{Ca}$ after extrusion 
does not significantly depend on the calcium content in the alloy. In the as-drawn wire (i.e., before annealing) grains were elongated in the material flow direction (e.g., Fig. 3b) which is typical for a hardened state.

The zinc was also recrystallized and exhibited equiaxed grains with grain size about $150 \mu \mathrm{m}$ (Fig. 5). A large grain size is typical for the recrystallized zinc.

Mechanical properties are collected in Table 2 and the typical stress-strain curves are shown in Fig. 6. Each test was repeated 3 times. The average values and standard deviation of the parameters obtained on the machine Zwick 250 are shown in Table 2. The hot extruded $\mathrm{Mg}-\mathrm{Ca}$ alloy wires show significantly higher strength than the zinc one (Table 2), and their strength increases with the calcium content in the range of $0.7-0.9 \%$. This result contradicts the data obtained for a cast material published by Wan et al. [52]. A further increase in the calcium content results in a much smaller increase in the strengthening of the alloy. With increasing calcium content elongation of hot extruded $\mathrm{Mg}-\mathrm{Ca}$ alloys is significantly reduced (from $26.7 \%$ for $\mathrm{MgCa} 0.7$ to $12.4 \%$ for $\mathrm{MgCa} 1.2$ ). This result also coincides with the data in [52].

Because the extruded rods from alloy $\mathrm{MgCa} 0.7$ combines significantly higher plasticity and only slightly lower strength characteristics than other $\mathrm{Mg}-\mathrm{Ca}$ alloys investigated

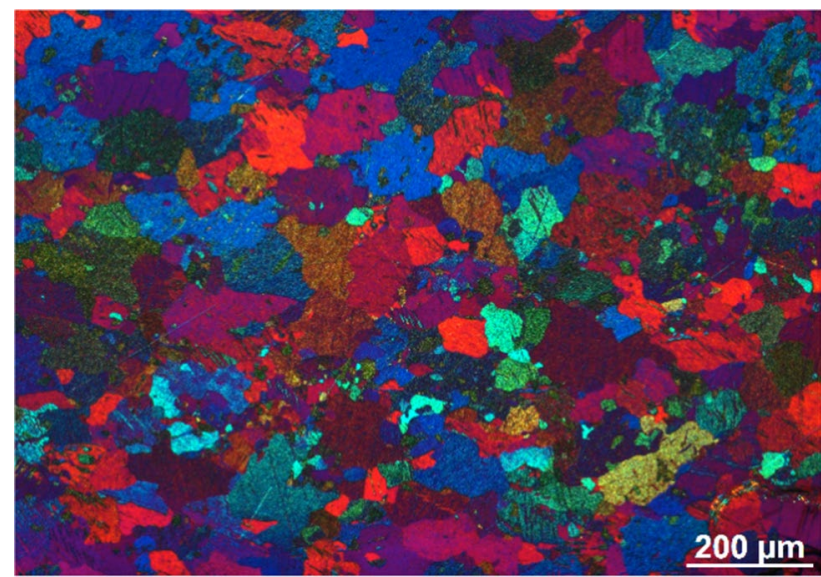

Fig. 5 Microstructure of the zinc wire after drawing. Longitudinal section, the horizontal axis is the direction of drawing. Light microscopy

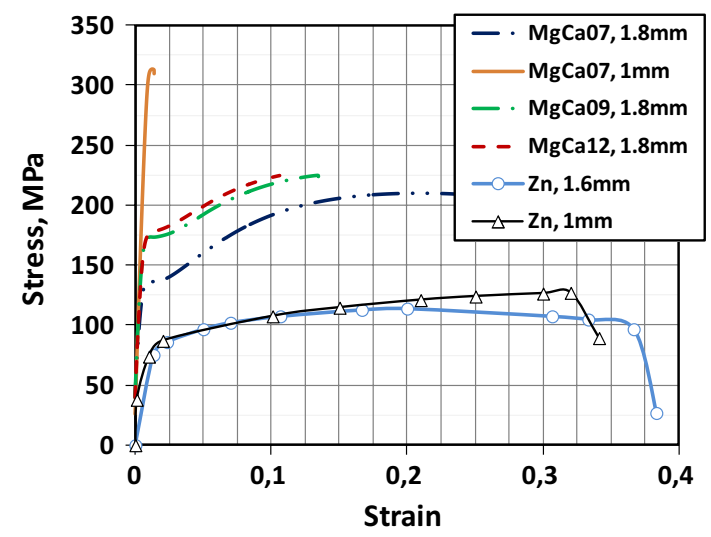

Fig. 6 The typical engineering stress-strain curves for $\mathrm{Zn}$ before drawing $(d=1.6 \mathrm{~mm})$ and after drawing $(d=1 \mathrm{~mm})$ and the alloys $\mathrm{Mg}-\mathrm{Ca}$ after extrusion $(d=1.8 \mathrm{~mm})$ and cold drawing $(d=1 \mathrm{~mm})$

in this research, this alloy was chosen for the room temperature drawing to a diameter of $1 \mathrm{~mm}$. However, the drawing of this alloy dramatically changes the mechanical properties of the wire compared to those measured directly after hot extrusion. So, the cold drawing significantly increased strength, but at the expense of the significant decrease in elongation. In addition, the standard deviation of the $\mathrm{Rm}$ and $\mathrm{Rp}$ increases significantly (Table 2), which is also unacceptable for using the material as a ST. Thus, such a material cannot be considered for a surgical thread. However, this material was also subjected to the corrosion test in order to evaluate the effect of cold drawing on the corrosion rate. It is worth to note that the room temperature drawing does not change the mechanical properties of $\mathrm{Zn}$, since the recrystallization temperature of $\mathrm{Zn}$ is close to room temperature.

\subsection{Corrosion test}

Experimental data showing the change in the sample mass during the corrosion test, collected in Fig. 7 demonstrate an increased corrosion rate of the alloy $\mathrm{MgCa} 0.7$ (both for the as-extruded and extruded and drawn wires). The fourteenday test result for $\mathrm{MgCa} 0.7$ with diameter of $1.8 \mathrm{~mm}$ was included to show a very high corrosion rate of this material. So, for the drawn alloy the percentage decrease in the sample
Table 2 Initial mechanical properties of tested materials

\begin{tabular}{lllrrr}
\hline & $D(\mathrm{~mm})$ & Production technology & $\mathrm{Rp}(\mathrm{YS})(\mathrm{MPa})$ & $\mathrm{Rm}(\mathrm{UTS})(\mathrm{MPa})$ & \multicolumn{1}{c}{$\mathrm{A}_{200}(\%)$} \\
\hline $\mathrm{MgCa} 0.7$ & 1.8 & Hot extrusion & $126.3 \pm 2.52$ & $210.3 \pm 1.15$ & $26.7 \pm 1.53$ \\
$\mathrm{MgCa} 0.9$ & 1.8 & Hot extrusion & $161.3 \pm 12.7$ & $228.3 \pm 4.51$ & $14.5 \pm 1.27$ \\
$\mathrm{MgCa} 1.2$ & 1.8 & Hot extrusion & $155.8 \pm 13.1$ & $224.0 \pm 5.35$ & $12.4 \pm 1.20$ \\
$\mathrm{MgCa} 0.7$ & 0.98 & Hot extrusion + cold drawing & $303.0 \pm 70.3$ & $309.0 \pm 71.6$ & $1.4 \pm 0.25$ \\
$\mathrm{Zn}$ & 1.6 & Properzi method & $51.6 \pm 0.90$ & $113.0 \pm 1.30$ & $37.6 \pm 0.90$ \\
$\mathrm{Zn}$ & 1.0 & Properzi method + cold drawing & $53.3 \pm 1.94$ & $126.0 \pm 2.20$ & $34.1 \pm 1.12$ \\
\hline
\end{tabular}




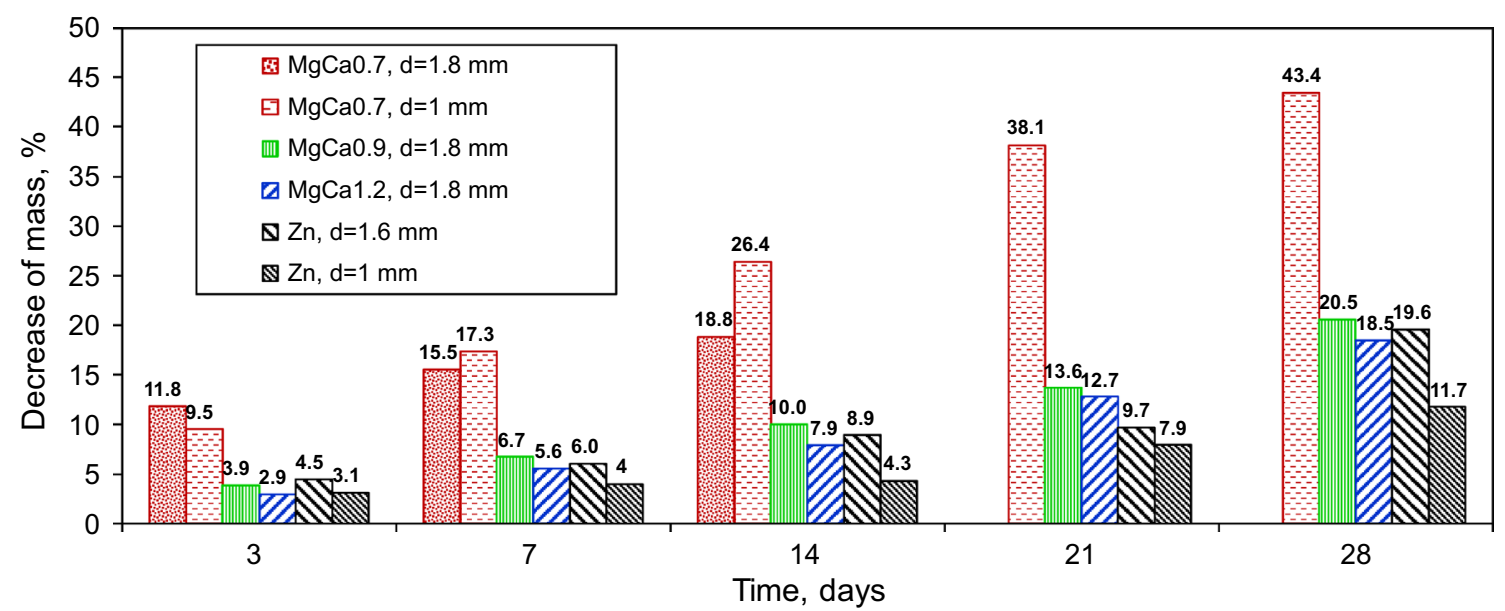

Fig. 7 Selected results of the corrosion tests performed according to ASTM F732-00 standard: material with diameter $d=1.8 \mathrm{~mm}$ is after extrusion, $d=1 \mathrm{~mm}$-after drawing and $d=1.6 \mathrm{~mm}$-after Properzi method of production

mass ( $y$ ) can be expressed by equation: $y=1.3743 \tau+6.8745$, where $\tau$ is the test time, in days. For this equation, the $R^{2}$ value is equal to 0.98 . The corrosion of the extruded alloy is slower (see Fig. 7) and it can be express as $y=0.6177 \tau$ $+10.425\left(R^{2}=0.965\right)$. For the other extruded alloys, with higher calcium contents, the equations can be expressed as: $y=0.6282 \tau+1.768\left(R^{2}=0.977\right)$ and $y=0.6008 \tau+0.7484$ $\left(R^{2}=0.9775\right)$ for alloys $\mathrm{MgCa} 0.9$ and $\mathrm{MgCa} 1.2$, respectively. So, two times smaller corrosion rate was observed when the calcium content in the alloy rose from 0.7 to $0.9 \%$. A further increase in calcium content to $1.2 \%$ has much less effect on the corrosion rate, similarly, as it was in the case of the mechanical properties. A significantly lower corrosion rate of the alloy $\mathrm{MgCa} 1$ in artificial plasma (i.e., the TasSBF solution) comparing to the alloy $\mathrm{MgCa} 0.5$ was noted also by Zakiyddin and Lee [51]. Our research results show that this effect can be related to a difference in the alloys microstructure. A relatively homogeneous microstructure with significantly smaller grains (e.g., about $10 \mu \mathrm{m}$ ) pertains to the alloys $\mathrm{MgCa} 0.9$ and $\mathrm{MgCa} 1.2$. On the other hand, the grain size of the as-extruded $\mathrm{MgCa} 0.7$ alloy exhibits a bimodal distribution (i.e., several micrometers and about $20 \mu \mathrm{m}$ - the value two times higher than for the alloys with the higher calcium content). Also, the corrosion rate for this alloy is two times greater. The grain size effect on the magnesium alloys corrosion resistance was previously addressed by Carlson et al. [65], Govind et al. [66] and Aung et al. [67]. So, according to our results, the effect of calcium content on the corrosion rate can be related to some reduction in the grain size, however, the $\mathrm{pH}$ shift of plasma toward greater alkalinity, due to the calcium dissolved in it, may also play a certain role. It has been shown that the corrosion rate of magnesium can be significantly changed by an increase in the $\mathrm{pH}$-value of a $\mathrm{NaCl}$ solution (i.e., the change from a linear surface limited reaction to the diffusion limited parabolic one [68]). The $\mathrm{pH}$ change may indeed have a certain effect in the case of the in vivo experiments. However, in our experiment, the $\mathrm{pH}$ value was kept constant, and thus it did not play an important role, if any. So, the influence of $\mathrm{CaMg}_{2}$ particles on corrosion rate can be rather related to the particles chemistry (i.e., the anodic index value, which is critical factor for the galvanic corrosion) and the matrix grain size. In summary, from the corrosion rate point of view, the calcium content in the alloys $\mathrm{Mg}-\mathrm{Ca}$ can be kept in the range of $0.9-1.2 \%$. However, before the recommendation of a particular alloy for some biomedical applications, it should be taken into account that corrosion characteristics of an alloy can be different in the different corrosive environments (e.g., in chemistry of a medium simulating body fluids) and depends also on corrosion tests details [69]. So, in vivo tests are always necessary.

The present experiments also showed that the average corrosion rate of the extruded alloys $\mathrm{Mg}-\mathrm{Ca}$, with calcium contents between 0.9 and $1.2 \%$, and the extruded zinc is similar, especially during the first 7-14 days of the corrosion test. However, the corrosion rate of zinc during the test is not as steady as it was for $\mathrm{Mg}-\mathrm{Ca}$ alloys. For the Properzi zinc $(d=1.6 \mathrm{~mm})$, a significant decrease in the mass change was observed between 14 and 21 day of the test, but more than the double increase in the corrosion rate was revealed during last 8 days of the test. So, the decrease in the mass versus the test time cannot be well expressed by a linear equation as it was for $\mathrm{Mg}-\mathrm{Ca}$ alloys. Instead, the much complicated function such as: $y$ $=0.003 \tau^{3}-0.1146 \tau^{2}+1.568 \tau+0.4172\left(R^{2}=0.987\right)$ must be used. The average corrosion rate of the drawn zinc is even lower and this process can be expressed by equation $y=0.0143 \tau^{2}+0.1066 \tau+3.5183\left(R^{2}=0.986\right)$. In this case, 
corrosion also clearly accelerates from 15 day of the test and in this period of the time it can be described by a linear function such as: $y=0.5286 \tau-3.1333\left(R^{2}=0.999\right)$. In this stage of the corrosion test the average corrosion rate is also lower for the drawn zinc than for the extruded one. One can speculate that decrease in the corrosion rate due to drawing can be related to some changes in the surface quality as well as to the grain size or to crystallographic texture developed during deformation. This explanation will be addressed in our future study. However, the corrosion rate of zinc, completely and partially immersed in the body, may differ substantially as was shown by Borgmann and Evans for a chloride solution environment [70]. This effect may be especially significant for some surgical threads.

\subsection{Corroded material}

\subsubsection{Microstructure of corroded layer}

Some plastic forming operations induced defects, such as scratches and minor cracks, that can be visible on the wires surface (as an example see Figs. 8a, 9a, 10a, 11a). Some corrosion traces were also present on the zinc surface (Fig. 8).

(a)

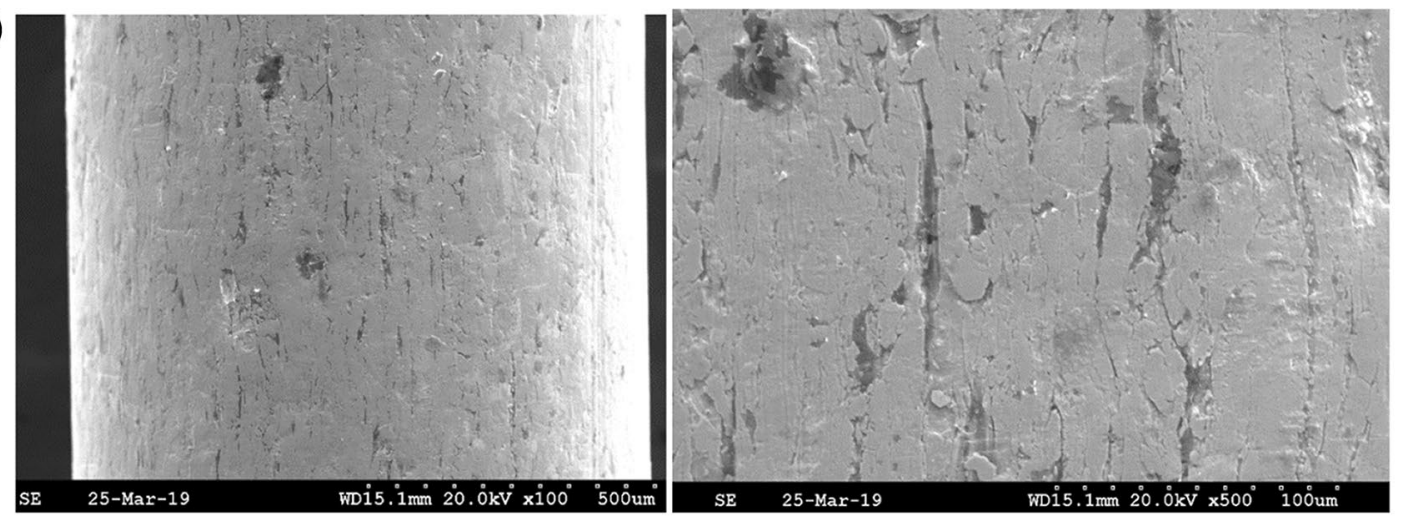

(b)

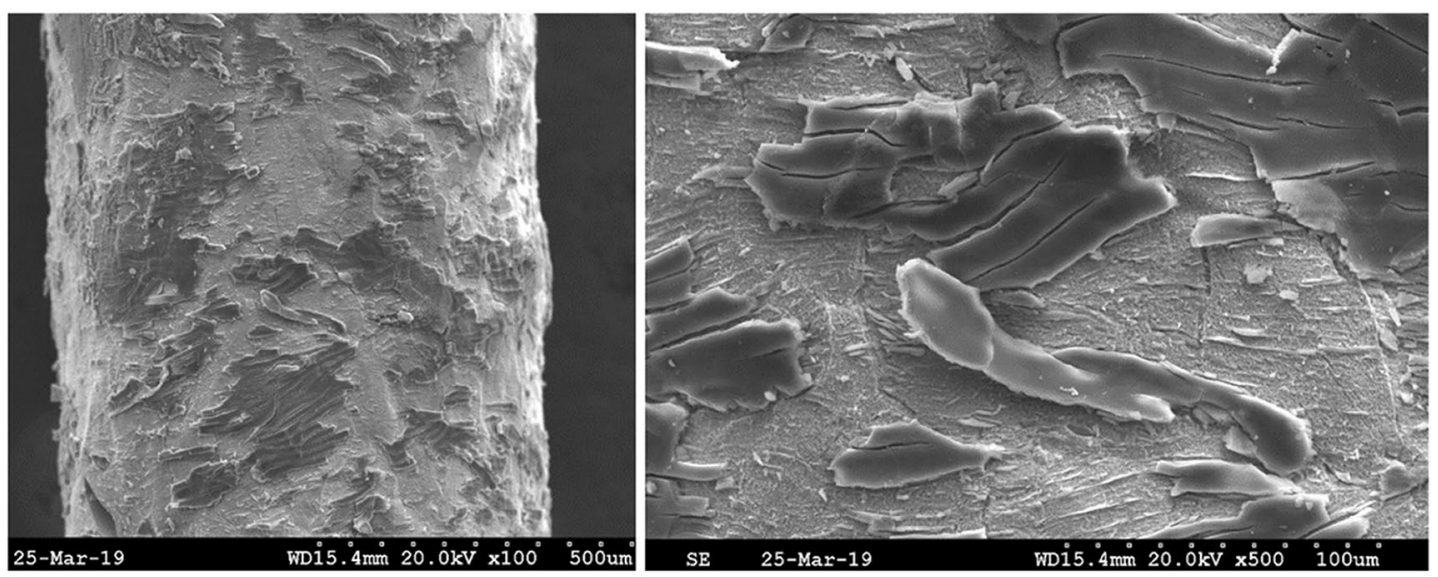

(c)



Fig. 8 Corrosion effects, $\mathrm{Zn}$ wire $(d=1.6 \mathrm{~mm})$. Material before corrosion test (a) and corroded material within 7 days $(\mathbf{b}), 35$ days $(\mathbf{c})$ 
Fig. 9 Corrosion effects, $\mathrm{MgCa} 0.7$ wire $(d=1 \mathrm{~mm})$. Material before corrosion test (a) and corroded material within, 7 days (b) and 28 days (c) (a)

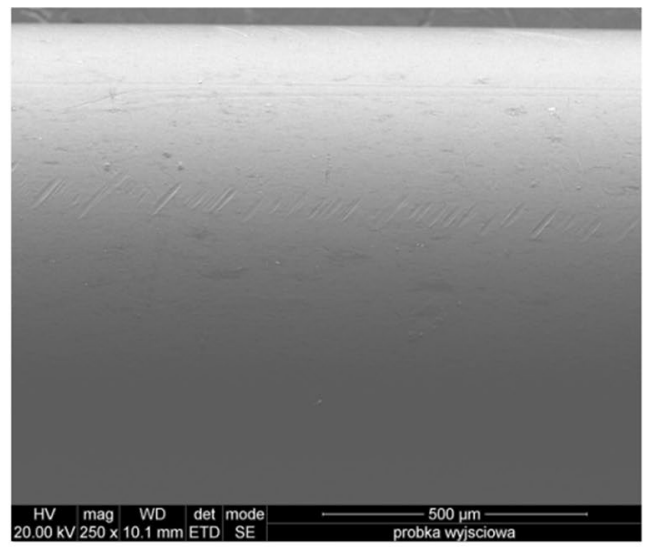

(b)
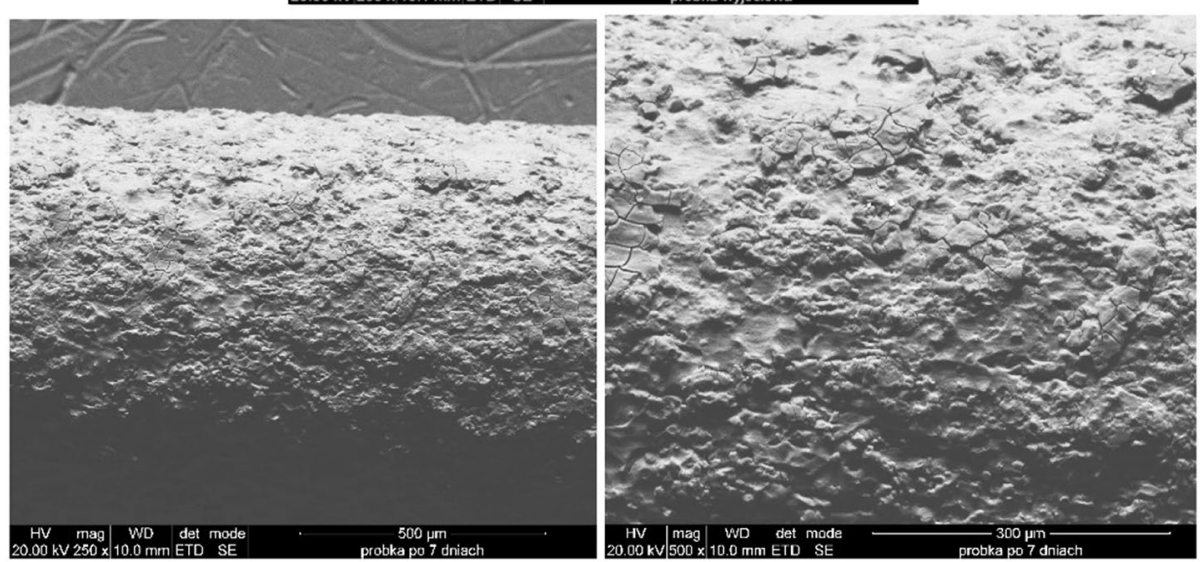

(c)

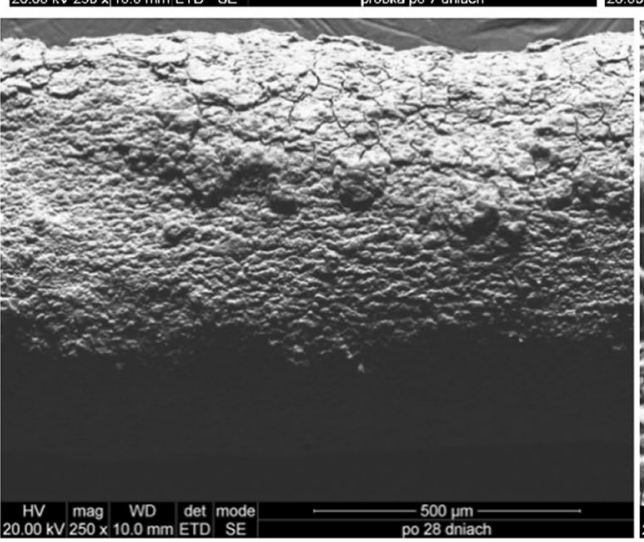

This is understandable because the native zinc oxide can react with water (even from the moisture) forming the zinc hydroxide which, in turn, easily forms zinc carbonate during reaction with carbon dioxide from air. Finally, zinc surface can be covered by a mixture of oxide, hydroxide and zinc carbonate. This coating can decrease the rate of further corrosion when the layer is thin and uniform. The layer of this type has a dark gray color and this color of layer covering zinc wires was detected in our study.

Relatively large flakes of corroded material, loosely associated with the substrate, are typical for the corrosion of zinc during the applied in vitro test (Fig. 8b-c). These flakes might be somehow related to the zinc grain size which is also relatively large (i.e., about $150 \mu \mathrm{m}$, Fig. 5). Despite of this, a change in the corroded wire diameter on the corroded wire length seems to be more uniform for zinc than for the $\mathrm{Mg}-\mathrm{Ca}$ alloys. A similar type of corroded zinc layer structure was observed for zinc exposed to plasma and to the Ringer's solution (see Fig. 6c and Fig. 6b in [71] respectively). However, the structure of corroded layer found in the present research is different from that observed by Liu et al. [72] for various media simulated body fluids (see Fig. 1 in [72]). In this case, the corroded layer exhibited a nodular shape and various zinc corrosion products density. It was also different from the microstructure observed by Meng et al. [73] on the pure zinc samples after exposure to a saline solution, where the corrosion products have a form of the nano-rods aggregates. The difference in microstructure can 
(a)
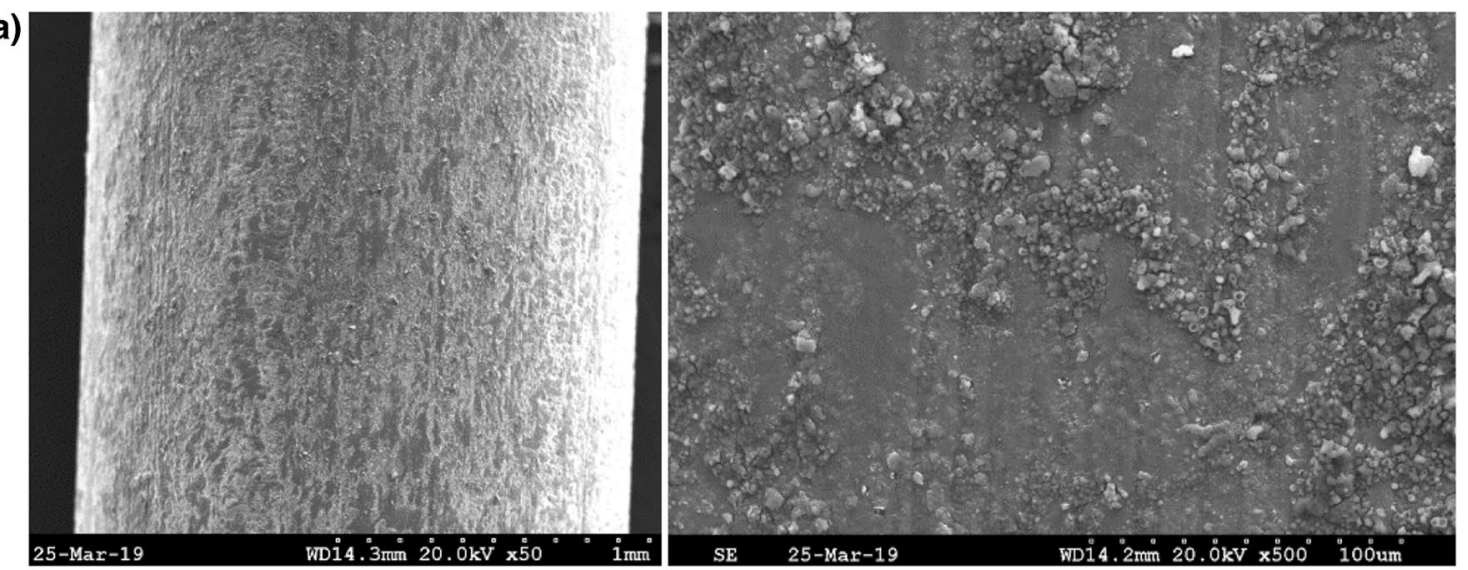

(b)
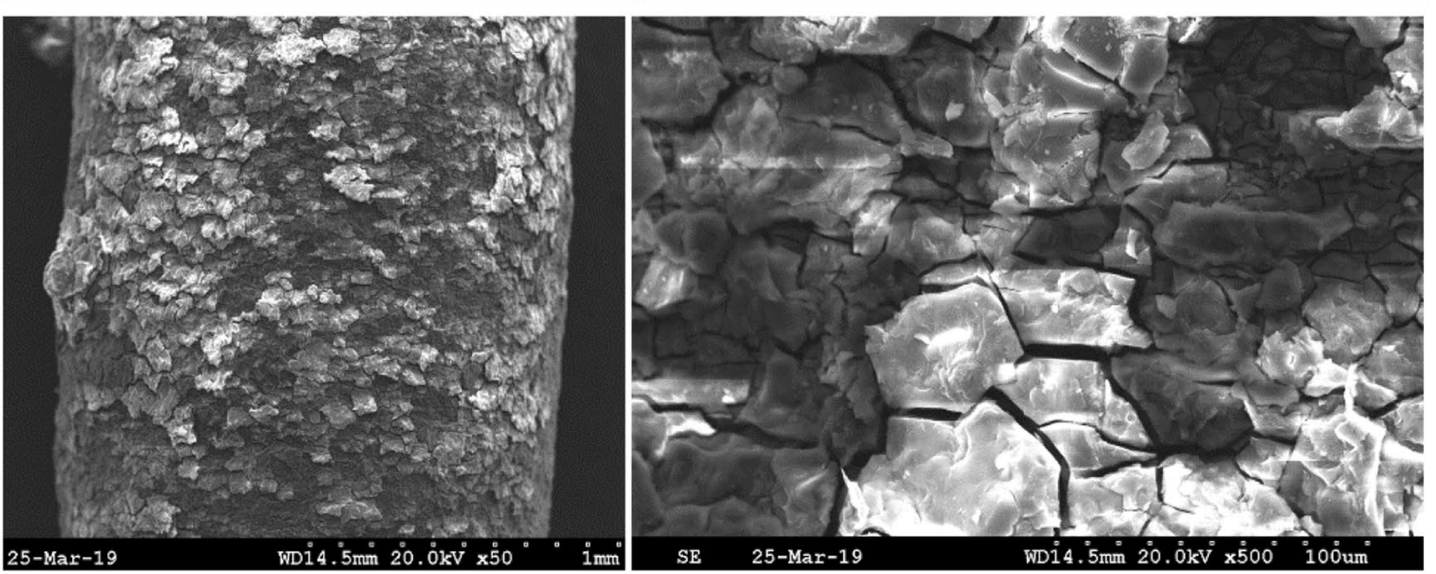

(c)
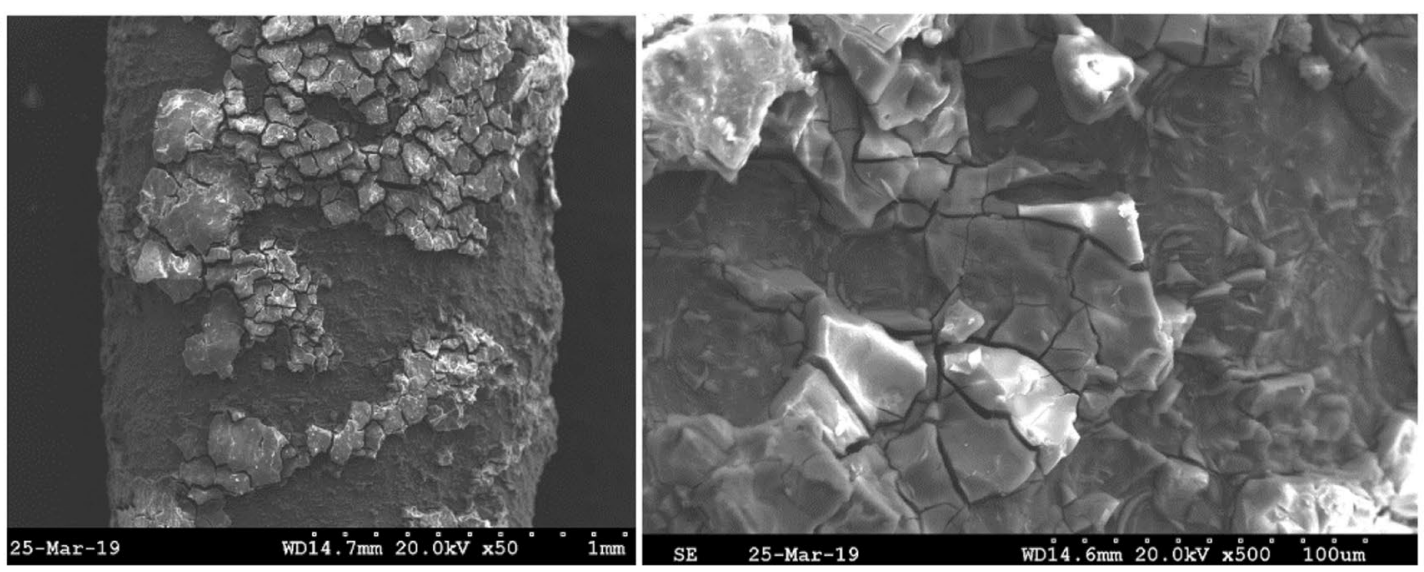

Fig. 10 Corrosion effects, $\mathrm{MgCa} 0.9$ wire $(d=1.8 \mathrm{~mm})$. Material before corrosion test (a) and corroded material within 7 days (b), 28 days (c)

result from a difference in experimental conditions (i.e., in the electrolyte chemistry and $\mathrm{pH}$ value). In our experiments, the $\mathrm{pH}$ value was kept constant, but in other experiments it was usually continuously altered (e.g., grooving in the experiment done by Meng et al. [73]). The $\mathrm{pH}$ value effect on the corroded layer microstructure was characterized by Thomas et al. [74] for corrosion of $99.99 \%$ pure zinc in aqueous solution of a chloride salt. In this case, for $\mathrm{pH}$ equal to 1, a slug-like zinc oxide uniformly covered zinc surface. This type of microstructure occurred in areas adjacent to the surface that were not attacked by corrosion and to other areas covered with nodules of zinc oxides, when $\mathrm{pH}$ was equal to 4 [74]. They also found that the nodular oxides density increased with increase in $\mathrm{pH}$, i.e., entire surface were covered by oxides at $\mathrm{pH} 10$ while at $\mathrm{pH} 13$ a continuous thick dense oxides layer was developed. However, in the present research rather a flake/lath form of the corrosion products were formed. So, it is believed that zinc corrosion can be sensitive to a difference in the corrosion conditions of the same mammalian's body and thus in vivo testing may be 
(a)
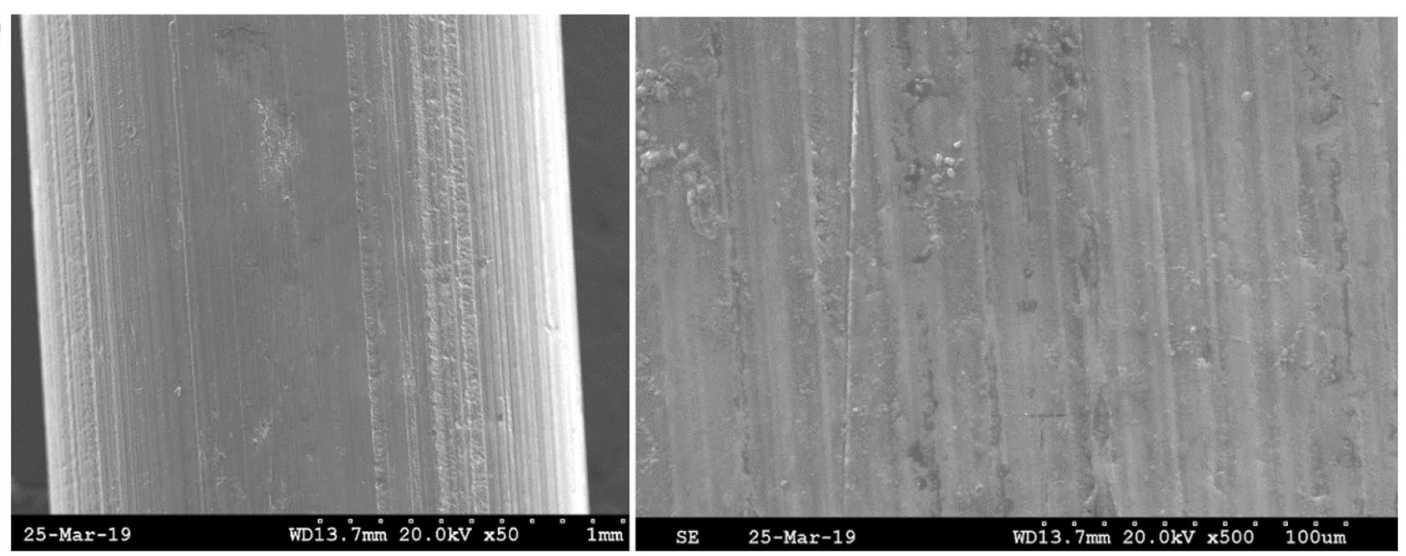

(b)
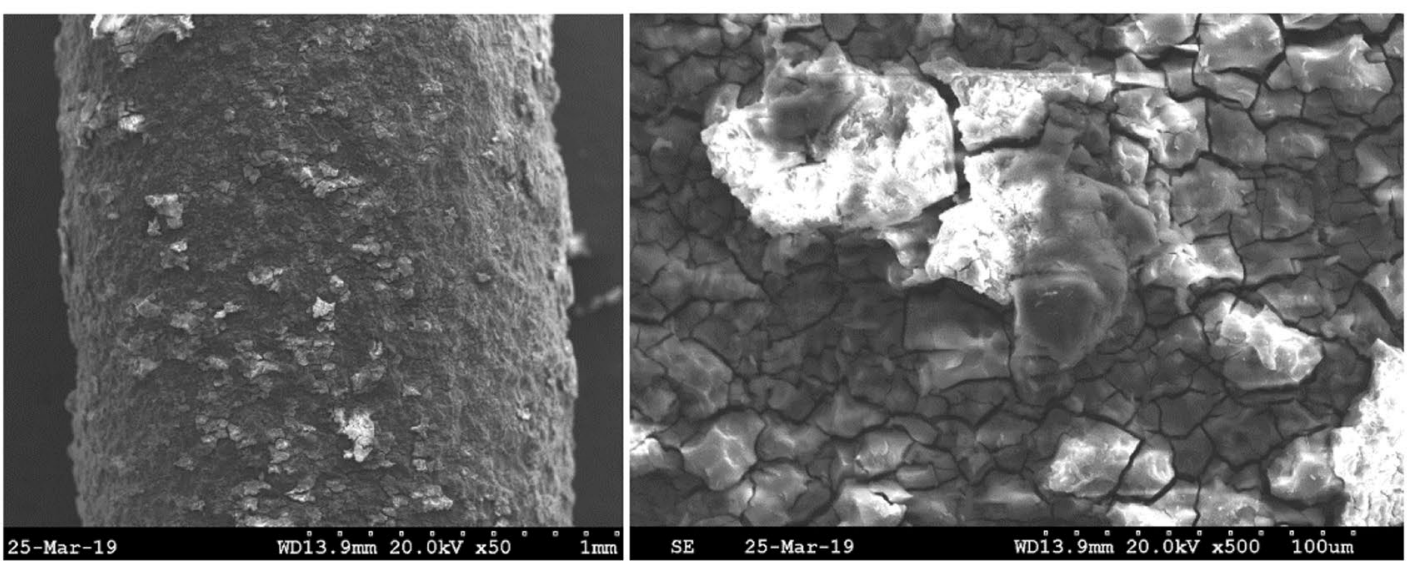

(c)
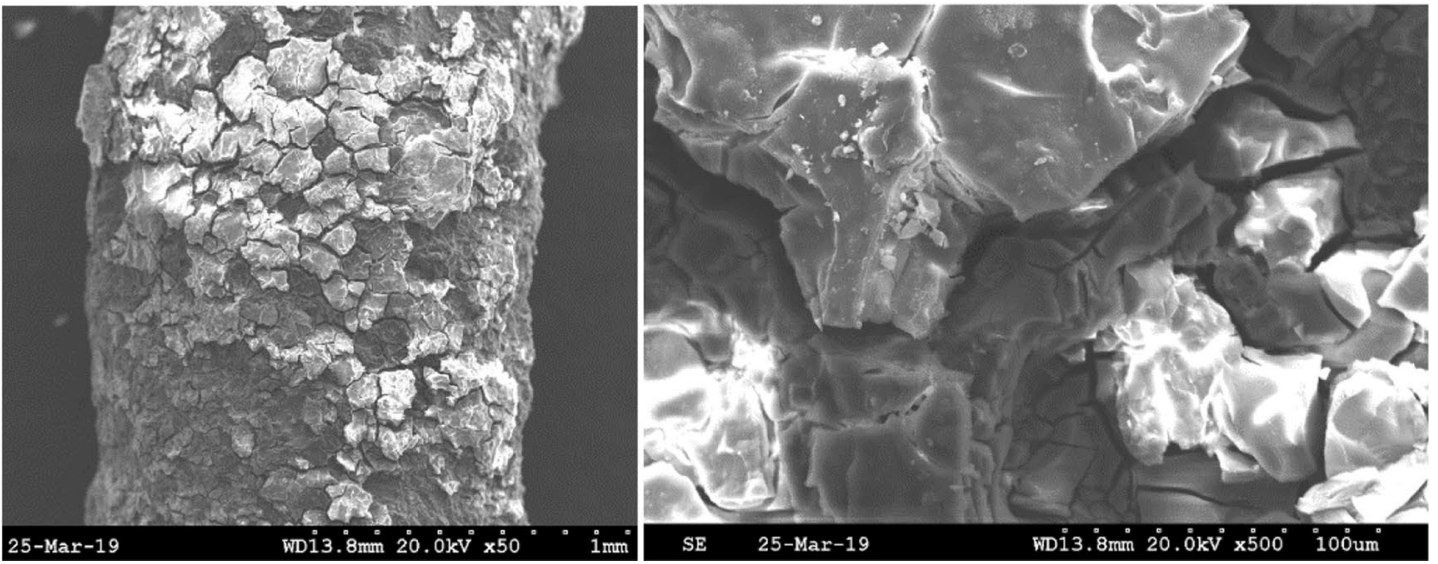

Fig. 11 Corrosion effects, $\mathrm{MgCa} 1.2$ wire $(d=1.8 \mathrm{~mm})$. Material before corrosion test $(\mathbf{a})$ and corroded material within 7 days $(\mathbf{b}), 35$ days $(\mathbf{c})$

unavoidable. However, our results clearly showed that some surface defects induced during applied processing route of the wire do not seem to be especially important from the corrosion point of view (compare Fig. 8a, c) which, in turn, can affect the mechanical properties of corroded metal.

Also magnesium is usually covered by the natural surface film, of which the chemistry and structure strongly depend on the environment, but the nature of such a film has not been thoroughly understood so far. However, it is well known that the oxide quite well protects magnesium at room temperature and there is no significant corrosion in air unless water is present [75]. In the presence of water, a white color magnesium hydroxide is formed by an electrochemical reaction that is accompanied by the release of a hydrogen. About $30 \%$ humidity in air is sufficient to see first traces of this corrosion, at about $80 \%$ humidity an amorphous hydroxide covered over $30 \%$ of the surface and for the humidity above $93 \%$ the transformation into the crystalline hydroxide was observed [76]. The solid magnesium hydroxide also can react with carbon dioxide and water to form the artinite 
(the magnesium hydroxyl carbonate) which can reduce the rate of corrosion [76]. The corrosion progress of $\mathrm{Mg}-\mathrm{Ca}$ alloys was completely different than in the case of zinc. Corrosion layer formed during in vitro test of the alloys was cracked, but flaky shape products of the corrosion appear to be much more strongly bonded to the substrate than in the case of zinc. Such a mechanism of the Mg corrosion is typical for environments with relatively low concentrations of the $\mathrm{Cl}^{-}$ions [62]. At high concentrations, typical pitting corrosion occurs. The size of corroded material flakes appears to increase as the calcium content in the investigated alloy increases. SEM images of corroded magnesium alloys similar to whose observed by us have been also shown by $\mathrm{Gu}$ et al. for the alloy Mg-1.22 wt\% Ca exposed to the Hank's solution (see Fig. 10c in [69]). The relatively fast corrosion of the $\mathrm{MgCa} 0.7$ alloy with a smaller corrosion flakes is surprising at first glance, but it can be related to the amount and distribution of the $\mathrm{CaMg}_{2}$ phase in the matrix (see Fig. 3) whose presence turned out to be beneficial, at least to the amount of $1.2 \%$ (see Fig. 7).

\subsubsection{Mechanical properties of corroded wires}

The local degradation of the $\mathrm{MgCa} 0.7$ wire was so high that it was not possible to mount the sample in the tensile setup; even after 3 days long corrosion test the samples broke during attachment attempts. So, this material could not been tested. This problem was not found for the other materials for which selected mechanical properties were determined and collected in Figs. 12, 13 and 14. Each datum shown in these figures is an average of several tests (at least three). It was found that corrosion does not significantly influences the Young's modulus value (Fig. 12). On the other hand, a strong effect on the ultimate tensile strength $(\mathrm{Rm})$ was observed (Fig. 13a). During the first 7 days of the corrosion test, the change in the value of relative strength (i.e.,

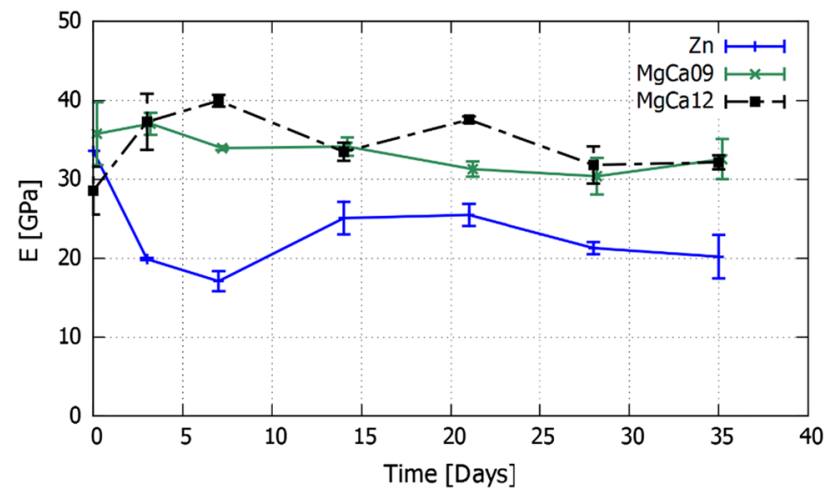

Fig. 12 Modification of the Young's modulus of samples in the corrosion process for $\mathrm{Zn}(d=1.6 \mathrm{~mm}), \mathrm{MgCa} 0.9$ and $\mathrm{MgCa} 1.2$ $(d=1.8 \mathrm{~mm})$
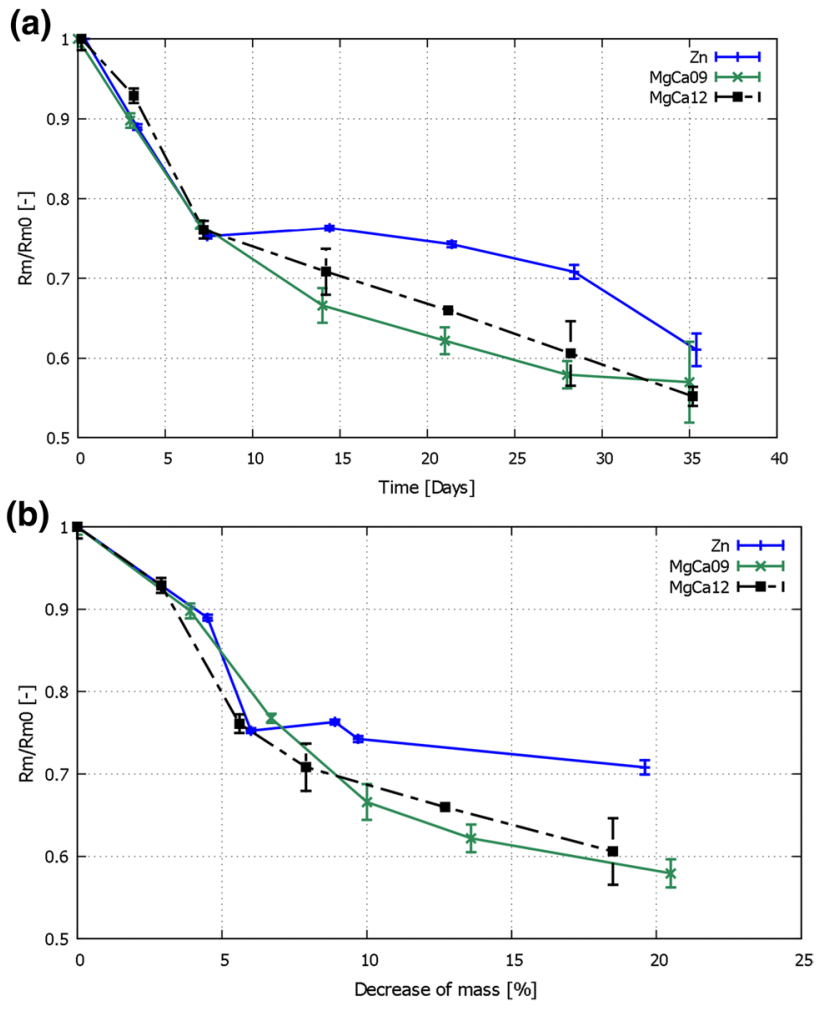

Fig. 13 Modification of the relative $\mathrm{Rm}$ of samples in the corrosion process for $\mathrm{Zn}(d=1.6 \mathrm{~mm}), \mathrm{MgCa} 0.9$ and $\mathrm{MgCa} 1.2(d=1.8 \mathrm{~mm})$ : a change of relative $\mathrm{Rm}$ in time; $\mathbf{b}$ relationship between relative $\mathrm{Rm}$ and decrease of mass

$\mathrm{Rm} / \mathrm{Rm}_{0}$, where $\mathrm{Rm}_{0}$ is the value for the material before the corrosion test) of $\mathrm{Zn}$ and $\mathrm{Mg}$ alloys with $0.9-1.2 \% \mathrm{Ca}$ was nearly the same. These materials have also very similar corrosion rate values in this period of the corrosion time. This was shown in Fig. 13b where the relative strength versus decrease in the mass during corrosion was shown. Between 7 and 21 corrosion days, the decrease in strength for zinc is lowest and for the alloy $\mathrm{MgCa} 0.9$ highest among

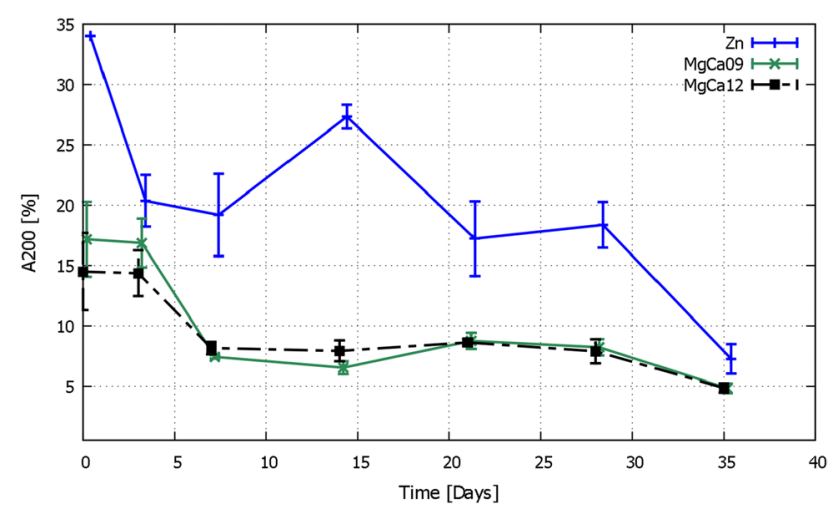

Fig. 14 Modification of the elongation of samples in the corrosion process for $\mathrm{Zn}(d=1.6 \mathrm{~mm}), \mathrm{MgCa} 0.9$ and $\mathrm{MgCa} 1.2(d=1.8 \mathrm{~mm})$ 
the materials tested, the reverse of the corrosion rate. A smoother surface of the corroded zinc wire can be responsible for lower reduction in the tensile strength compared to the case of the magnesium alloys wires despite nearly the same decrease in the sample mass during corrosion.

For zinc, a minimum is observed on the dependence of Young's modulus on corrosion time (Fig. 12). This minimum is also visible for the elongation (Fig. 14). The position of this minimum also corresponds to a sharp change in the course of the curve in Fig. 13. The magnitude of the observed changes exceeds the standard error, also shown in these figures. Thus, the observed phenomenon cannot be explained by the experimental error. A possible explanation for these results may be this phenomenon is due to the nature of zinc corrosion. In the first stages, corrosion occurs unevenly. This leads to the appearance of stress concentrators. In the future, however, the surface after corrosion becomes smoother (Fig. 8c). This reduces the stress concentration and leads to the restoration of the original values of Young's modulus and elongation. However, we do not have sufficient evidence for such an explanation. These results therefore need to be interpreted with caution.

The corrosion effect on the tensile elongation is illustrated in Fig. 14. Regardless of the corrosion time, the zinc tensile elongation is significantly higher than for $\mathrm{Mg}-\mathrm{Ca}$ alloys with $0.9-1.2 \% \mathrm{Ca}$, for which the elongation value is only slightly dependent on the Ca contents in the alloy. However, even for these alloys tensile elongation throughout investigated corrosion period is higher than 5\% and this value can be considered as sufficient for an application to the STs.

In summary, it is believed that the $\mathrm{Mg}-\mathrm{Ca}$ alloys with about $0.9-1.2 \%$ Ca can be recommended as a candidate for the surgical threads. This conclusion is in agreement with results published by of Wan et al. [52] and Li et al. [77] where similar alloys were tested as candidates for the bone implants. Moreover, our research results have shown that the smoother surface of the corroded zinc wire slows down the decrease in its tensile strength. This also makes zinc a promising material for the STs manufacture.

\section{Conclusions}

The paper showed results of the in vitro corrosion in bovine serum on the mechanical properties of new candidate materials for manufacture of the high strength biodegradable surgical threads (i.e., $\mathrm{Zn}$ and selected $\mathrm{Mg}-\mathrm{Ca}$ alloys with $0.7-1.2 \% \mathrm{Ca}$ ). It was shown that the corrosion products have relatively large flakes shape and poor adhesion. The rate of tested materials biodegradation is high but any biomedical application requires in vivo tests determining an effect of the corrosion products accumulation in the body. The other most important conclusions are given below.
1. An increase in calcium content in the range of $0.7-1.2 \%$ homogenizes the $\mathrm{Mg}-\mathrm{Ca}$ alloy microstructure, reduces the grain size of the alloys matrix, increases the density of $\mathrm{CaMg}_{2}$ particle distribution and slightly decreases the rate of corrosion in a bovine serum.

2. The room temperature drawn alloy $\mathrm{MgCa} 0.7$ shows relatively large rate of corrosion in a bovine serum (i.e., about $29 \%$ for the 14 day test). The corrosion rate of this alloy was so high that made it impossible to recommend this alloy for the future in vivo tests. So, this alloy turns out to be unsuitable for the use as a candidate for surgical threads.

3. In the entire corrosion period of 35 days, reduction in strength of $\mathrm{Zn}$ and alloys $\mathrm{MgCa} 0.9$ and $\mathrm{MgCa} 1.2$ was below $50 \%$ of its initial value, plasticity of these materials was not less than 5\% and the Young's modulus was not significantly changed. So, these materials can be recommended as candidates for surgical threads.

4. During corrosion, the zinc wire forms a smoother surface than the magnesium alloy wire. This leads to a decrease in stress concentration and, as a result, to a smaller loss of strength with the same decrease in mass. Zinc also has better ductility than magnesium alloys. These factors make zinc also a good candidate for the manufacture of surgical sutures.

Acknowledgements Investigation is conducted within project no. POIR.04.01.04-00-0074/17 named: "Comprehensive development and preparation for the implementation of innovative implant solutions in the treatment of animals, surgical instruments for their implantology and biodegradable surgical thread for veterinary medicine" Action 4.1 "Research and Development", Subaction 4.1.4 "Application projects" Operational Program Smart Growth 2014-2020 co-financed from the European Regional Development Fund.

\section{Compliance with ethical standards}

Conflict of interest The authors declare that they have no conflict of interest.

Ethical standard The authors state that ethical standards were not violated when preparing the paper.

Open Access This article is licensed under a Creative Commons Attribution 4.0 International License, which permits use, sharing, adaptation, distribution and reproduction in any medium or format, as long as you give appropriate credit to the original author(s) and the source, provide a link to the Creative Commons licence, and indicate if changes were made. The images or other third party material in this article are included in the article's Creative Commons licence, unless indicated otherwise in a credit line to the material. If material is not included in the article's Creative Commons licence and your intended use is not permitted by statutory regulation or exceeds the permitted use, you will need to obtain permission directly from the copyright holder. To view a copy of this licence, visit http://creativecommons.org/licenses/by/4.0/. 


\section{References}

1. Ress A. The cyclopedia or universal dictionary of arts, sciences, and literature, vol. XXXIV. London: Longman, Hurst, Rees, Orme \& Brown; 1918.

2. https://medical-dictionary.thefreedictionary.com/ligature. Accessed 2 Dec 2019.

3. Saber A. Ancient Egyptian surgical heritage. J Investig Surg. 2010. https://doi.org/10.3109/08941939.2010.515289.

4. Dobanovicki D, Milovanovic L, Slavkovic A, Tatic, MIskovic SS, Skoric-Jokic S, Pecanac M. Surgery before common era (B.C.E). Arch Oncol. 2012. https://doi.org/10.2298/aoo1202028d.

5. Levine H. Stitch in time: 18 fascinating facts about the history of sutures. New Brunswick: Jonson \& Jonson Co.; 2016.

6. https://www.jnj.com/our-heritage/history-of-sutures-ethicon. Accessed 2 Dec 2019.

7. Snelling N. The history of the suture, from ancient Egypt to Nobel Prizes: delve into the history of stitches. Medibank. 2015. https://www.medibank.com.au/livebetter/be-magazine/wellb eing/the-history-of-the-suture/. Accessed 2 Dec 2019.

8. Cutajar L. Sutures and ligatures in surgery. St. Luke's Hosp Gazette. 1957;10:51-3.

9. Muffly TM, Tizzano AP, Walters MD. The history and evolution of sutures in pelvic surgery. J R Soc Med. 2011. https://doi. org/10.1258/jrsm.2010.100243.

10. General specifications of surgical stitching materials. Katsan Surgical Sutures. KatsanKatgutSanayyve Tic A/S. 2019. https:// katsanas.com/general-specifications-of-surgical-stitching-mater ials. Accessed 2 Dec 2019.

11. Surgical needles. SERAG-WIESSNER GmbH \& Co. https:// www.serag-wiessner.de/en/products/surgical-needles/. Accessed 2 Dec 2019

12. Horse hair sutures. Willis-Knighton Talbot Medical Museum. https://museum.wkhs.com/collections/online-collections/detai 1s/horse-hair-sutures. Accessed 2 Dec 2019.

13. Kronemyer B. Human hair to suture facia wounds? The aesthetic channel. 2017. https://www.aestheticchannel.com/cosme tic-surgery/human-hair-suture-facial-wounds. Accessed 2 Dec 2019.

14. Holder EJ, Pharm B. The story of catgut. Postgrad Med J. 1949;25:427-33.

15. Goldstain JH, Clahane AC, Bedrossian PB, Copeland RL. Comparison of catgut and collagen sutures in strabismus surgery. Am J Ophthalmol. 1971;71:935-9.

16. Thilagavathi G, Viju S. Silk as a suture material. In: Basu A, editor. Ch. 11 in Advances in silk science and technology, 1 st edn. Woodhead Publishing Series in Textiles; 2015. p. 219-32.

17. Babcock WW. Metallic sutures and ligatures. Surg Clin N Am. 1947;27:61435-60.

18. Barrows T. Degradable implant materials: a review of synthetic absorbable polymers and their applications. Clin Mater. 1986;1:233-57.

19. Middleton JC, Tipton AJ. Synthetic biodegradable polymers as orthopedic devices. Biomaterials. 2000;21:2335-46.

20. Bostman O, Pihlajamaki H. Clinical biocompatibility of biodegradable orthopaedic implants for internal fixation: a review. Biomaterials. 2000;21:2615-21.

21. Seitz JM, Durisin M, Goldman J, Drelich JW. Recent advances in biodegradable metals for medical sutures: a critical review. Adv Healthc Mater. 2015. https://doi.org/10.1002/adhm.20150 0189.

22. Anderson JM, Shive MS. Biodegradation and biocompatibility of pLa and pLGa microspheres. Adv Drug Deliv Rev. 2012;64:72-82.
23. Bergsma EJ, Rozema FR, Bos RR, De Bruijn WC. Foreign body reactions to resorbable poly(l-lactide) bone plates and screws used for the fixation of unstable zygomatic fractures. J Oral Maxillofac Surg. 1993;51:666-70.

24. Daniels AU, Chang MK, Andriano KP, Heller J. Mechanical properties of biodegradable polymers and composites proposed for internal fixation of bone. J Appl Biomater. 1990. https://doi. org/10.1002/jab.770010109.

25. Marques DR, dos Santos LA, Schopf LF, de Fraga JCS. Analysis of poly(lactic-co-glycolic acid)/poly(isoprene) polymeric blend for application as biomaterial. Polímeros. 2013. https://doi. org/10.4322/polimeros.2013.099.

26. Meyle J. Suture material and suture techniques. Perio Periodontal Pract Today. 2006;3:253-68.

27. Morreale M, Mistretta MCh, Fiore V. Creep behavior of poly(lactic acid) based biocomposites. Materials. 2017. https:// doi.org/10.3390/ma10040395.

28. Edlich RF, Drake BD, Rodeheaver GT, Winters KL, Greene JA, Gubler KD 3rd, Long WB, Britt LD, Winters SP, Scott CC, Lin KY. Syneture stainless steel suture. A collective review of its performance in surgical wound closure. J Long Term Eff Med Implants. 2006;16(1):101-10.

29. Radha R, Sreekanth D. Insight of magnesium alloys and composites for orthopedic implant applications-a review. J Magnes Alloys. 2017;5:286-312.

30. Fekry AM. Electrochemical corrosion behavior of magnesium alloys in biological solutions. In: Czerwiński F, editor. Ch. 5 in Magnesium alloys - corrosion and surface treatments. InTech Publ.; 2011. p. 65-92; ISBN 978-953-307-972-1.

31. Zhang S, Zhang X, Zhao Ch, Li J, Song Y, Xie Ch, Tao H, Zhang Y, He Y, Jiang Y, Bian Y. Research on an Mg-Zn alloy as a degradable biomaterial. Acta Biomater. 2010;6:626-40.

32. Jamesh M, Kumar S, Narayanan TSNS. Corrosion behavior of commercially pure $\mathrm{Mg}$ and ZM21 Mg alloy in Ringer's solutionlong term evaluation by EIS. Corros Sci. 2011;53:645-54.

33. Zhang BP, Wang Y, Geng L. Research on Mg-Zn-Ca alloy as degradable biomaterial. In: Pignatello R, editor. Ch. 9 in biomaterials-physics and chemistry. In Tech Publ. ; 2011. pp. 183-204; ISBN 978-953-307-418-4.

34. Chiu KY, Wong MH, Cheng FT, Man HC. Characterization and corrosion studies of fluoride conversion coating on degradable $\mathrm{Mg}$ implants. Surf Coat Technol. 2007. https://doi.org/10.1016/j.surfc oat.2007.06.035.

35. Waizy H, Weizbauer A, Modrejewski Ch, Witte F, Windhagen H, Lucas A, Kieke M, Denkena B, Behrens P, Meyer-Lindenberg A, Bach FW, Thorey F. In vitro corrosion of ZEK100 plates in Hank's balanced salt solution. Biomed Eng. 2012. https://doi. org/10.1186/1475-925X-11-12.

36. Levy GK, Goldman J, Aghion E. The prospects of zinc as a structural material for biodegradable implants-a review paper. Metals. 2017. https://doi.org/10.3390/met7100402.

37. Peuster M, Wohlsein P, Brugmann M, Ehlerding M, Seidler K, Fink C, Brauer H, Fischer A, Hausdorf G. A novel approach to temporary stenting: degradable cardiovascular stents produced from corrodible metal-results 6-18 months after implantation into New Zealand white rabbits. Heart. 2001. https://doi. org/10.1136/heart.86.5.563.

38. Seitz JM, Utermöhlen D, Wulf E, Klose C, Bach FW. The manufacture of resorbable suture material from magnesium. Adv Eng Mater. 2011;13:1087-95.

39. Witte F, Hort N, Vogt C, Cohen S, Kainer KU, Willumeit R, Feyerabend F. Degradable biomaterials based on magnesium corrosion. Curr Opin Solid State Mater Sci. 2008;12:63-72.

40. Seitz JM, Eifler R, Stahl J, Kietzmann M, Bach FW. Characterization of $\mathrm{MgNd}_{2}$ alloy for potential applications in bioresorbable implantable devices. Acta Biomater. 2012;8:3852-64. 
41. Grote KH, Antonsson EK. Springer handbook of mechanical engineering. New York: Springer; 2009.

42. Schinhammer M, Hänzi AC, Löffler JF, Uggowitzer PJ. Design strategy for biodegradable Fe-based alloys for medical applications. Acta Biomater. 2010. https://doi.org/10.1016/j.actbi o.2009.07.039

43. Porter F. Zinc handbook: properties, processing, and use in design. New York: M. Dekker; 1991.

44. Vojtech D, Kubásek J, Serák J, Novák P. Mechanical and corrosion properties of newly developed biodegradable $\mathrm{Zn}$-based alloys for bone fixation. Acta Biomater. 2011. https://doi.org/10.1016/j.actbi o.2011.05.008.

45. Milenin A, Kustra P, Wróbel M, Paćko M, Byrska-Wójcik DJ. Comparison of the stress relaxation of biodegradable surgical threads made of $\mathrm{Mg}$ and $\mathrm{Zn}$ alloys and some commercial synthetic materials. Arch Metall. 2019. https://doi.org/10.24425/ amm.2019.129506.

46. Yuan W, Li B, Chen D, Zhu D, Han Y, Zhen Y. Formation mechanism, corrosion behavior, and cytocompatibility of microarc oxidation coating on absorbable high-purity zinc. ACS Biomater Sci Eng. 2019;5:487-97.

47. Drelich AJ, Zhao S, Guillory RJ, Drelich JW, Goldman J. Longterm surveillance of zinc implant in murine artery: Surprisingly steady biocorrosion rate. Acta Biomater. 2017;58:539-49.

48. Witte F. The history of biodegradable magnesium implants: a review. Acta Biomater. 2010. https://doi.org/10.1016/j.actbi o.2010.02.028

49. Lambotte A. Technique et indications de prothèse perdue dans la traitement des fractures. Press Med Belge. 1909;17:321-3.

50. Verbrugge J. Le matériel métallique résorbable en chirurgie osseuse. La Press Medicale. 1934;3:460-5.

51. Zakiyuddin A, Lee K. Effect of a small addition of zinc and manganese to $\mathrm{Mg}-\mathrm{Ca}$ based alloys on degradation behavior in physiological media. J Alloys Compd. 2015;629:274-83.

52. Wan Y, Xiong G, Luo H, He F, Huang Y, Zhou X. Preparation and characterization of a new biomedical magnesium-calcium alloy. Mater Des. 2008. https://doi.org/10.1016/j.matdes.2008.04.017.

53. Milenin A, Kustra P, Byrska-Wójcik D, Grydin O, Schaper M, Mentlein T, Gerstein G, Nürnberger F. Analysis of microstructure and damage evolution in ultra-thin wires of the magnesium alloy MgCa0.8 at multipass drawing. JOM. 2016;68(12):3063-9.

54. Kustra P, Milenin A, Byrska-Wójcik D, Grydin O, Schaper M. The process of ultra-fine wire drawing for magnesium alloy with the guaranteed restoration of ductility between passes. J Mater Process Technol. 2017;247:234-42.

55. https://www.biowest.net. Accessed 2 Dec 2019

56. Chu CC. Mechanical properties of suture materials, an important characterization. Ann Surg. 1981;93(3):365-71.

57. Williamson GK, Hall WH. X-ray line broadening from filed aluminum and wolfram. Acta Met. 1953;1:22-31.

58. Mezbahul-Islam M, Mostafa AO, Medraj M. Essential magnesium alloys binary phase diagrams and their thermochemical data, review article. J Mater. 2014. https://doi.org/10.1155/2014/70428 3.

59. Aljarrah M, Medraj M. Thermodynamic modelling of the $\mathrm{Mg}-\mathrm{Ca}$, $\mathrm{Mg}-\mathrm{Sr}, \mathrm{Ca}-\mathrm{Sr}$ and $\mathrm{Mg}-\mathrm{Ca}-\mathrm{Sr}$ systems using the modified quasichemical model. Comput Coupling Phase Diagr Thermochem. 2008;2:240-51.

60. Zhong Y. Investigation in $\mathrm{Mg}-\mathrm{Al}-\mathrm{Ca}-\mathrm{Sr}-\mathrm{Zn}$ system by computational thermodynamics approach coupled with first-principles energetics and experiments, $\mathrm{PhD}$ Thseis, Avedesian: The Pensylvania State University; 2005.

61. Baker MM. ASM specialty handbook, magnesium and magnesium alloys. Materials Park: ASM International; 1999.

62. Liu CL, Wang YJ, Zeng RC, Zhang XM, Huang WJ, Chu PK. In vitro corrosion degradation behaviour of $\mathrm{Mg}-\mathrm{Ca}$ alloy in the presence of albumin. Corros Sci. 2010;52:3341-7.

63. Dryzek J, Wróbel M, Dryzek E. Recrystallization in severely deformed $\mathrm{Ag}, \mathrm{Au}$, and $\mathrm{Fe}$ studied by positron-annihilation and XRD methods. Phys Status Solidi B. 2016;253:2031-42.

64. Dryzek J, Wróbel M. Observation of the recrystallization process in pure $\mathrm{Nb}$ and $\mathrm{Zr}$ using positron lifetime pectroscopy and XRD techniques. Phys Status Solidi B. 2018;225:1-7.

65. Carlson BE, Jones JW. The metallurgical aspects of the corrosion behaviour of cast $\mathrm{Mg}-\mathrm{Al}$ alloys. In: CIM conference, light metals processing and applications. Quebec; 1993. P. 833-47.

66. Govind Nair KS, Mittal MC, Lal K, Mahanti RK, Sivaramakrishnan CS. Development of rapidly solidified (RS) magnesium-aluminium-zinc alloy. Mater Sci Eng. 2001;304:520-3.

67. Aung N, Zhou W. Effect of heat treatment on corrosion and electrochemical behaviour of AZ91D magnesium alloy. J Appl Electrochem. 2002;32:1397-401.

68. Malteseva A, Shkirskiy V, Lefèvre G, Volovitch P. Effect of pH on $\mathrm{Mg}(\mathrm{OH})_{2}$ film evolution on corroding $\mathrm{Mg}$ by in situ kinetic Raman mapping (KRM). Corros Sci. 2019;153:272-82.

69. Gu XN, Zheng YF, Chen LJ. Influence of artificial biological fluid composition on the biocorrosion of potential orthopedic Mg-Ca, AZ31, AZ91 alloys. Biomed Mater. 2009. https://doi. org/10.1088/1748-6041/4/6/065011.

70. Borgmann CW, Evans UR. The corrosion of zincin chloride solutions. J Electrochem Soc. 1934;65(1):249-74.

71. Törne K, Larsson M, Norlin A, Weissenrieder J. Degradation of zinc in saline solutions, plasma, and whole blood. J Biomed Mater Res B. 2016. https://doi.org/10.1002/jbm.b.33458.

72. Liu X, Yang H, Liu Y, Xiong P, Guo H, Huang HH, Zheng Y. Comparative studies on degradation behavior of pure zinc in various simulate body fluids. JOM. 2019. https://doi.org/10.1007/ s11837-019-03357-3.

73. Meng Y, Liu L, Zhang D, Dong Ch, Yan Y, Volinsky AA, Wang $\mathrm{LN}$. Initial formation of corrosion products on pure zinc in saline solution. Bioact Mater. 2019;4:87-96.

74. Thomas S, Birbills N, Venkatraman MS, Cole IS. Corrosion of zinc as a function of $\mathrm{pH}$. Corrosion. 2012. https://doi. org/10.5006/1.3676630.

75. Lindstom R, Johansson L, Thompson G, Skeldon P, Svensson J. Corrosion of magnesium in humid air. Corros Sci. 2004;46:1141-58.

76. Hu H, Nie X, Ma Y. Corrosion and surface treatment of magnesium alloys. In: Czerwinski F, editor. Ch. 3 in magnesium alloysproperties in solid and liquid states. London: Intech Published; 2014. p. 67-108.

77. Li Z, Gu X, Lou S, Zheng Y. The development of binary Mg-Ca alloys for use as biodegradable materials within bone. Biomaterials. 2008. https://doi.org/10.1016/j.biomaterials.2007.12.021.

Publisher's Note Springer Nature remains neutral with regard to jurisdictional claims in published maps and institutional affiliations. 